Recepción: 29/08/16

Evaluación: 30/08/16

Aprobación: 20/10/16

Artículo de Investigación Científica

\title{
LA MASONERÍA EN MIRANDA, MUTIS Y ZEA (PARA UNA HISTORIOGRAFÍA DE LA FRANCMASONERÍA LATINOAMERICANA)
}

\author{
José Pascual Mora García* \\ Universidad Pedagógica y Tecnológica de Colombia \\ Grupo Hisula-Ilac \\ pascualmoraster@gmail.com
}

\begin{abstract}
RESUMEN
A la tradición de las Luces masónicas y su influencia en la construcción de la independencia las ha reconocido poco la historiografía tradicional. En este trabajo, se propone develar los aportes de Sebastián Francisco de Miranda, José Celestino Mutis y, su discípulo, Francisco Antonio Zea. Igualmente, se quiere significar su influencia en la construcción de la ciencia moderna en la Nueva Granada. La Expedición Botánica, liderada por el sabio José Celestino Mutis, es la pionera no solo por llevar los conceptos de la ciencia moderna, sino es el patriarca fundador de principios paramasónicos de los ideólogos de la independencia neogranadina. Se sigue el método de la historia de las mentalidades, representaciones e imaginarios, que analiza no solo los criterios de la historia positiva, sino los "andamios mentales" de las contribuciones de los científicos neogranadinos, especialmente aquellos que tuvieron formación masónica.
\end{abstract}

Palabras claves: expedición botánica, masonería, mentalidad.

* Filósofo (Universidad Central de Venezuela, 1986); Magister en Gerencia Educativa (UNET-1994); Doctor en Historia (USM, 2002); Doctor en Pedagogía en Innovación y Sistema Educativo (URVEspaña, 2009). Profesor Titular Emérito de la Universidad de Los Andes, Núcleo "Dr. Pedro Rincón Gutiérrez". Past coordinador General de Postgrado de la Universidad de Los Andes-Táchira (20122015). Investigador en la máxima categoría, nivel C, según evaluación del Observatorio Nacional de Ciencia, Tecnología de Investigación e Innovación (Oncti 2011-2013). Ratificado en la evaluación en la máxima categoría, nivel C (2013-2015). Investigador reconocido por Colciencias, Colombia, como investigador del Grupo de Investigación de Historia de la Universidad Latinoamericana (Hisula- ILACUPTC, Tunja). Pastpresidente de la red Shela y Primer Accesit del Premio Nacional de productividad de las universidades venezolanas, 2014. Actualmente, Investigador responsable como editor de la Revista Latinoamericana de DDHH de la UPTC, Tunja. Así como proyectos de Investigación vinculados con el Grupo HISULA-UPTC, Tunja; HEDURE-ULA-Táchira. 


\title{
MASONRY IN MIRANDA, MUTIS AND ZEA (FOR A HISTORIOGRAPHY OF LATIN AMERICAN FRANCMASONRY)
}

\begin{abstract}
The tradition of Masonic Enlightenment and its influence on the construction of independence has been scarcely recognized by traditional historiography. In this paper, we proposed to unveil the contributions of Sebastián Francisco de Miranda, José Celestino Mutis and his disciple, Francisco Antonio Zea. Likewise, it is meant to influence the construction of modern science in New Granada. The Botanical Expedition, led by the sage José Celestino Mutis, is pioneer not only for carrying the concepts of modern science, but also because he is the patriarch founder of paramasonic principles of the ideologues of Neogranadine independence. This research follows the method of the history of mentalities, representations and imaginaries, which analyzes not only the criteria of positive history, but also the "mental scaffolds" of the contributions of Neogranadian scientists, especially those who had Masonic training.
\end{abstract}

Key words: botanical expedition, masonry, mentalilty.

\section{A MAÇONARIA EM MIRANDA, MUTIS Y ZEA (PARA UMA HISTORIOGRAFÍA DE LA FRANCMASONERÍA LATINOAMERICANA)}

\begin{abstract}
RESUMO
A tradição da iluminação maçônica e sua influência na construção da independência tem sido pouco reconhecida pela historiografia tradicional. Neste trabalho, propõe-se desvendar as contribuições de Sebastián Francisco de Miranda, José Celestino Mutis e seu discípulo Francisco Antonio Zea. Do mesmo modo, pretende influenciar a construção da ciência moderna em Nova Granada. A Expedição Botânica, liderada pelo sábio José Celestino Mutis, é pioneira não só para levar os conceitos da ciência moderna, mas também o patriarca fundador dos princípios paramaçonico dos ideólogos da independência da Neogranadina. Ele segue o método da história das mentalidades, representações e imaginários, que analisa não apenas os critérios da história positiva, mas os "andaimes mentais" das contribuições de cientistas neogranadinos, especialmente aqueles que tiveram formação maçônica.
\end{abstract}

Palavras-chave: expedição botânica, maçonaria, mentalidade. 


\section{INTRODUCCIÓN}

"El secreto y el juramento constituyeron el factor sine qua non de la emancipación americana, presentes como estaban en las colonias tanto la estricta y cruel vigilancia de las autoridades españolas, como la actividad de la Inquisición. Sólo el secreto de la conspiración y la consiguiente coordinación entre los revolucionarios, secreta asimismo, pudieron conducir al éxito final de la conspiración. Miranda, iniciado ahora en Gibraltar, utilizará el poderío masónico en forma extraordinaria; y todos los capitanes que con él conspiraron".

Alfonso Rumazo, Francisco de Miranda.

El trabajo que aquí se presenta se inició en el año 2000, cuando se desarrolló el Seminario de Postgrado Historia de las Mentalidades en la Universidad de Los Andes, Táchira, por el Dr. Juan Manuel Santana, de la Universidad de Las Palmas de Gran Canarias. El Pbro. José del Rey Fajardo, entonces rector de la Universidad Católica del Táchira, me invitó a trabajar a José Ferrer Benimeli. En especial, porque parte de la comunidad científica hispanoamericana todavía considera poco serios a quienes se atrevan a pensar y menos a abordar el tema. De manera que considero necesario, de manera preliminar, ubicar el estado del arte del tema de la masonería en los procesos de independencia como tema histórico e historiográfico. Se resalta una limitación historiográfica que ha traído como consecuencia el no contar con verdaderos historiadores de la francmasonería, problema que no solo es potestativo de la historiografía venezolana, sino de la historia masónica en general, como lo explica Ferrer Benimeli: "la historia de la masonería, tanto en el lado masónico como en el 'profano', no ha sido escrita por historiadores, sino por aficionados (...) Debido a esta ausencia de auténticos historiadores, la francmasonería se encontró durante cierto tiempo entregada fundamentalmente en manos de dos categorías de escritores: los detractores y los turiferarios; a los que en nuestros días habría que añadir una tercera clase: la de los periodistas y novelistas dados al sensacionalismo fácil y la imaginación desbordada"1.

No obstante el trabajo más completo que presenta un estado del arte en América Latina es de José Antonio Ferrer Benimeli², “Aproximación a la historiografía de

1. José Ferrer Benimeli, Bibliografía de la masonería. Introducción histórico-crítica. Caracas: Universidad Católica "Andrés Bello", 1974), 17.

2. José Antonio Ferrer Benimeli es Doctor en Historia (1972), Profesor Titular Emérito de Historia Contemporánea, Fundador y Presidente de Honor del Centro Estudios Históricos de la Masonería Española, Universidad de Zaragoza, España; su obra como masonólogo supera los 70 libros; en Venezuela, se editaron: José Ferrer Benimeli, Bibliografía de la masonería. Introducción históricocrítica (Caracas: Universidad Católica "Andrés Bello", 1974); Los archivos secretos vaticanos y la masonería. Motivos políticos de una condena pontificia (Caracas, Universidad Católica "Andrés Bello", 1976). 


\section{la masonería latinoamericana"3 y aparte de este se pregunta por los autores y obras $^{4} \mathrm{y}$, sobre todo, ¿cuáles son los textos publicados por Academias, ${ }^{5} \operatorname{Redes}^{6} \mathrm{y}$ Centros $^{7}$ y Grupos de Investigación?, ${ }^{8}$ ¿cuáles son las Revistas?,9 ¿cuáles son los}

3. José Antonio Ferrer Benimeli (2009), “Aproximación a la historiografía de la masonería latinoamericana", Rehmlac 4, no 1, (mayo-noviembre 2012):2-121. (Agradezco al autor la mención de mis trabajos al respecto: José Pascual Mora García, "Los comuneros, Francisco de Miranda y la francmasonería en Venezuela (1779-1810)", Heurística 11 (enero-junio, 2009):74-92, www.saber. ula.ve/bitstream/123456789/30649/1/articulo7. pdf; José Pascual Mora García, "La Masonería. Su historia y su contribución en la construcción simbólica de la nación venezolana”. En Liberalismo, Masonería e Independencia en Hispanoamérica, coord. Moisés Guzmán Pérez (Morelia, México: 2011, en prensa).

4. En Venezuela, el más prolífico es Eloy Reverón García, Influjos masónicos en la instauración del matrimonio civil y registros civiles para nacimientos, matrimonios y defunciones (Caracas: Academia Nacional de la Historia, 1988); Influjos masónicos en la Instauración del Matrimonio Civil (Caracas: EMU, 1990), 28 p.; Masonería en Venezuela (Siglo XIX) (Caracas: UCV/Escuela de Historia, 1992), 144 p.; Masonería desnuda (Caracas: Ed. IVEM, 1994), 133 p.; Crisis de la Masonería Venezolana (Siglo XX) (Caracas: Instituto de Altos Estudios Diplomáticos "Pedro Gual"/Cátedra de Historia de Venezuela Contemporánea, Profesor Manuel Caballero, 1995), 38 p.; "Mito y Realidad en la Historiografía masónica”, Bolivarium 4 (1995), Sartenejas, U.S.B.; "Memoria Masónica de Venezuela" en: Historia para todos 17 (Caracas, Profesores, U.C.V., 1996); "El Fantasma de Bolívar en la Masonería Venezolana”, Bolivarium 6 (1997), Sartenejas, U.S.B.; “Cómo se originó la creencia de que Miranda fue masón?” (martes, 20 de mayo de 2008), http://masoneriamirandina.blogspot.com

5. Eloy Reverón García, Influjos masónicos en la instauración del matrimonio civil y registros Civiles para nacimientos, matrimonios y defunciones (Caracas, Academia nacional de la Historia, 1988); Manuel Pérez Vila, , "La Experiencia masónica de Bolívar en París”, en Visión Diversa de Bolívar (Ciclo de Charlas en homenaje al Libertador con motivo del año bicentenario de su natalicio) (Caracas: Pequiven, 11 de mayo de 1983; 1993), 331-41; “La Experiencia masónica de Bolívar en París", en Aportes a la Historia documental y crítica (Estudios, monografías y ensayos 73) (Caracas: Academia Nacional de la Historia, 1996), 127-44. Y referencias colaterales en Fulgencio López, Juan de Picornell y la conspiración de Gual y España (2ª ed. Caracas: Academia Nacional de la Historia, 1997), 441 p.

6. En la Redinternacional Vendimia se destaca el trabajo de José Pascual Mora-García (2010) “Los masones en la construcción simbólica de la nación venezolana (Del Estado protonacional a la conformación del Estado Nación decimonónico)." En Diana Soto Arango; Justo Cuño Bonito; José Tomás Uribe; y Olga Acuña, eds., La Construcción de la nación Iberoamericana. Siglos XIX a XXI. Conceptos y Métodos para la Historia y la Construcción de la Nación. (Tunja: Rudecolombia/Doctorado en Ciencias de la Educación/UPTC/Centro Vendimia/Grupo Hisula, 2010), 159-78.

7. En México, del Centro de Estudios Históricos de la Masonería Latinoamericana y Caribeña, Cehmlac.

8. El Grupo de Investigación Hedure, de la Universidad de Los Andes-Táchira, desarrolla una línea de investigación sobre Historia de las mentalidades, representaciones e imaginarios, al interior de la cual José Pascual Mora García desarrolla el tema de la Historia de la masonería en Venezuela y América Latina.

9. La más representativa es la Revista de Estudios Históricos de la Masonería Latinoamericana y Caribeña (Rehmlac), una publicación electrónica académica multidisciplinaria semestral, adjunta al Programa de Estudios Históricos de la Masonería y Sociedades Patrióticas en Centroamérica, inscrito en la Escuela de Estudios Generales de la Universidad de Costa Rica (UCR). En Venezuela, se destacan algunos trabajos publicados en: Cfr. Carmen Gómez Liendo, "La masonería en Venezuela. Influencia en la emancipación”, en Anuario de Estudios Bolivarianos 1 (1990):45-107. Cfr. Eloy Reverón García, “Mito y realidad en la historiografía masónica (1808-1830)”, en Anuario de Estudios Bolivarianos, Instituto de Investigaciones Históricas Bolivarium 4, n 1 (1995):261-335; "Memoria Masónica de Venezuela", en Historia para todos 17 (Caracas: Profesores, U.C.V., 1996); "El Fantasma de Bolívar en la Masonería Venezolana" en Bolivarium 6 (1997), Sartenejas, U.S.B. Cfr. Francisco Franco, "Masonería, librepensamiento y catolicismo en la Mérida de finales del siglo XIX." Presente y pasado: revista de historia 3, n 5 (ene.-jun. 1998):23-55, Mérida. En la Revista digital de Historia de la Educación (Heurística), cfr. José Pascual Mora García, "Los comuneros, Francisco de Miranda y la francmasonería en Venezuela (1779-1810)", Heurística 11 (enero-junio 2009):74-92, www.saber.ula. ve/bitstream/123456789/30649/1/articulo7.pdf (Mérida, Venezuela) 11. 
Congresos, ${ }^{10}$ Coloquios, ${ }^{11}$ Symposium, ${ }^{12}$ Seminarios ${ }^{13}$ y Cátedras Libres?, ${ }^{14}$ ¿cuáles son las tesis doctorales ${ }^{\mathbf{1 5}}$ o de maestría ${ }^{\mathbf{1 6}}$ sobre el tema? Esta aclaratoria preliminar es oportuna porque aún, en algunos escenarios académicos, al mencionar el tema de la masonería, casi se lo debe hacer sotto voce; incluso, en ciertas Academias de Historia y/o espacios académicos, el tema de la masonería es tabú y excusa para excluir el académico, o someterlo a "un tratamiento balcánico".

No hay duda que la historiografía tradicional ha estigmatizado el tema de la masonería como hecho histórico e historiográfico, y algunos autores consideran que casi habría que desecharlo de entrada; a juzgar por las tendencias de los historiadores dedicados al tema de la independencia, no es ni siquiera a considerar; así lo han

10. Los Congresos realizados por convocaría de universidades y científicos sociales en América Latina son muy pocos, si se compara con otros temas; en particular, se recuerdan algunos de los organizados en Latinoamérica: Marcos González Pérez (1999), en Colombia; y Moisés Guzmán (2011), en México. En Venezuela, Mario Briceño Perozo, "Los masones en la Independencia. La obra de Carnicelli", en VI Congreso Venezolano de Historia (Caracas, A.N.H., 1998), 24 p. En Leiden-Holanda, en el marco del XV Congreso Internacional de Ahila, realizado en la Universidad de Leiden entre el 25 y 29 de agosto 2008, se realizó el Simposio: Los antagonismos durante el período independentista hispanoamericano que coordinó Edda Samudio; allí se presentó la ponencia de José Pascual Mora García, "Comuneros y Masones en los Movimientos Precursores de la Independencia de Venezuela, el mito comunero y los masones en la invención de la tradición proto-nacional. (1779-1810)." Por nuestra parte, se incorporó una mesa sobre Sociedades Secretas e Independencia; Cfr. José Pascual Mora García (2009), I Congreso Internacional de Historia: Mentalidades, Representaciones e Imaginarios; José Pascual Mora García, coord., II Congreso Internacional de Historia: Mentalidades, Representaciones e Imaginarios (San Cristóbal: Grupo Hedure-ULA, 2010), http://www.saber.ula.ve/ handle/123456789/30446

11. IX Coloquio de Historia Social y de la Ciencia, con el tema: La masonería en la independencia, organizado por el Grupo de Investigación La Ilustración, en Ilustración en América Colonial-ILAC, que se realizó en Cartagena los días 20 al 24 de marzo de 2014; el evento tuvo lugar en la Casa de la Serenísima gran Logia Nacional de Colombia.

12. Los dos primeros Symposium de Historia de la Masonería Latinoamericana y Caribeña. Cfr. Ricardo Martínez Esquivel, "Simposios Internacionales de Historia de la Masonería Latinoamericana y Caribeña (La Habana, Cuba, 2007 y 2008)”, Rehmlac, Revista de Estudios Históricos de la Masonería Latinoamericana y Caribeña 1, n 2 (dic. 2009-abril 2010): 159-167 (San José, Costa Rica), rehmlac. com/recursos/vols/v1/n2/ rehmlac.vol1.n2-543rich.pdf. Luego, los días 2-4 de diciembre de 2010 se realizó el III Symposium internacional de historia de las masonerías y las sociedades patrióticas latinoamericanas y caribeñas: Masonería, independencia, revolución y secularización, en el marco del Bicentenario de la Independencia de México, del Centenario de la Revolución Mexicana y del Sesquicentenario de la promulgación de las Leyes de Reforma; convocado por la Universidad Nacional Autónoma de México (UNAM), el Museo Nacional de Arte MUNAL, el Recinto de Homenaje a Don Benito Juárez del Palacio Nacional y el Grupo México del Centro de Estudios Históricos de la Masonería Latinoamericana y Caribeña, Cehmlac.

13. En el VI Seminario Taller Internacional Vendimia, Educación y Construcción de la Nación en América Latina y el Caribe: Historia y Prospectiva, realizado en la UPTC-Tunja entre el 7 y 9 de noviembre de 2012, y coordinado por Alba Nidia Triana y Aracely Forero, se realizó el Simposio No. 5, Francmasonería y Benthamismo en los procesos de independencia de la Nueva Granada y Venezuela, Coordinado por José Pascual Mora García. En este evento, se desatacó la ponencia del Dr. Javier Ocampo López, intitulada: “El obispo masón Juan Fernández de Sotomayor y Picón." Cfr. Javier Ocampo López, El cura Juan Fernández de Sotomayor y Picón y los catecismos de la Independencia (Bogotá: Universidad del Rosario, 2010).

14. La Cátedra de Historia de la Masonería en la Universidad Central de Venezuela, Caracas.

15. En Venezuela, se reseña la tesis doctoral de Juan de Dios López Maya "Música, masonería y poder en la Venezuela del siglo XIX", Universidad Central de Venezuela, Facultad de Humanidades y Educación, Comisión de estudios de postgrado, Doctorado en Humanidades, línea de investigación: historia de la música en Venezuela, 2010.

16. Jasmina Mejía Singer. "Logia Masónica Estrella de Occidente de Barquisimeto, 1861-1970", resultado de su tesis de maestría en historia en la UCLA, Barquisimeto, Venezuela. 
manifestado caros historiadores. Son pocos los que abiertamente han considerado capítulos sobre el tema, ${ }^{17}$ o un apartado tímido o referencia sobre el tema.

Desde el punto de vista historiográfico, el tratamiento del tema masónico ha merecido un mejor trato al interno de la metodología de la historia de las mentalidades, a pesar de que los grandes representantes de la Escuela de Annales no le hubieran reconocido mayor importancia, pero, obviamente, es uno de los temas que forman parte del underground de los que Le Goff ${ }^{18}$ sugiere que deben desenterrarse para la Nueva Historia.

En efecto, Ferrer Benimeli (1974) no registra ni un solo representante de la Escuela de Annales, en su voluminoso libro sobre Bibliografía masónica. Pero se debe reconocer que, desde la década del sesenta del siglo pasado, con la tercera y cuarta generación de la Escuela de Annales, comienza a tener estelaridad; representa el esfuerzo por escribir la historia, como dijera Eric Hobsbawm, ${ }^{19}$ "mirando desde abajo", ${ }^{20}$ pero con sentido científico.

La historiografía francesa, específicamente de la Escuela de Annales, acuñó la expresión Historia de las Mentalidades para caracterizar el estudio de temas hasta ese momento considerados marginales de la Historia. A partir de ese momento, el estudio de la vida privada, las actitudes, las creencias, la historia de la mujer, el amor, el sexo, las prácticas de lectura, los rituales, las relaciones amorosas, la muerte, y la masonería, así como los temas que lindan con la patología social, comenzaron a ser centro de gravedad de la investigación histórica. Y uno de esos temas es la masonería, tal como lo han evidenciado los trabajos citados de José Ferrer Benimeli. Ahora, al adentrarse en el tema, con esta mirada preliminar, porque la historia de las mentalidades ha sido una línea de investigación desarrollada en mis investigaciones, ${ }^{21}$ bajo la tradición historiográfica fundada por el Dr. Federico Brito Figueroa en Venezuela, y la escuela de historiadores continuada por el Dr. Reinaldo Rojas, al interior de esta escuela de historiadores en Venezuela, el tema sobre la masonería ha sido objeto de estudio como trabajo de maestría ${ }^{22}$

17. Recientemente, en Colombia, es destacable el capítulo del libro: "Juan Fernández de Sotomayor y la masonería”, en Javier Ocampo López, (2010) El cura Juan Fernández de Sotomayor y Picón y los catecismos de la Independencia Bogotá: Universidad del Rosario, 2010).

18. Jacques Le Goff, "Historia de las mentalidades: Una historia ambigua..."

19. Eric Hobsbawm y Terence Ranger, eds., La invención de la tradición (Barcelona: Crítica, 2002).

20. La expresión "mirar la historia desde abajo" (history from below) es un concepto que busca reivindicar la historia de los anónimos en la Historia social; se enfoca en la perspectiva de la gente común, en vez de la de los líderes políticos. Aunque la expresión es del historiador francés Georges Lefebvre (18741959), y la desarrollaron y popularizaron historiadores marxistas británicos en los años 1960; entre ellos, Christopher Hill, Eric Hobsbawm, Raphael Samuel, R. Hilton y E. P. Thompson.

21. Cfr. José Pascual Mora García. Historia social de las mentalidades y de la educación en la vicaría foránea de La Grita, en el tiempo histórico de la Diócesis de Mérida de Maracaibo (1778-1922). Editada por la Universidad de los Andes, con el título: La Dama, el Cura y el Maestro en el siglo XIX (Mérida: Consejo de Publicaciones, 2004).

22. Cfr. Yasmina Mejía. "Historia Social de la masonería en el Estado Lara: Respetable Logia "Estrella de Occidente" $\mathrm{N}^{\circ} 50$ (1856-1960).” Barquisimeto: Mimeo Universidad Centroccidental Lisandro Alvarado, UPEL-IP Luis Beltrán Prieto Figueroa, Maestría en Historia. 2005. Trabajo tutoreado por el Dr. Luis Cortes Riera. 
que, aunque no hace aportes en materia historiográfica, es un gran esfuerzo por incorporar el tema de las logias masónicas al oficio de historiador.

Al realizar un esfuerzo de clasificación de las diferentes tendencias sobre la historia de la masonería, siguiendo a Ferrer Benimeli (1974), se diría que los hay de tres tipos: 1. los detractores; 2 . los turiferarios; y, agrego, en tercer lugar, a los dilettantes, jalonados por la visión sensacionalista y la búsqueda de mercados para sus libros. La emergencia de los movimientos de la Nueva Era ha despertado la proliferación de libros sin fundamentación epistemológica ni método histórico, cuyo fin es aprovechar las excentricidades para producir sensacionalismo en la industria cultural y de consumo. Se va a ver en qué consisten esas tres tendencias.

La primera tendencia, los detractores, se empeñan en develar los secretos de la orden al gran público, y la idea del complot masónico contra en el Ancién Régime. Se empeñan en desprestigiar a la masonería al vincularla al tema antisemita, satánico, y hasta comunista (como fue el caso del Franquismo en España). Esta influencia ejerce una visión maniquea a todas luces, sin bases y fundada en pseudo-verdades, preñada de juicios más políticos que reales. Se ha masificado esta tendencia en nuestros países, e incluso en el mundo académico, tanto que algunos todavía piensan que los masones "comen niños."

Durante la independencia, fue célebre el sermón del cura José Antonio de Torres, párroco de Tabio, Santafé, en la Oración fúnebre del obispo de Santafé de Bogotá del día 22 de abril de 1817,y que el gran historiador de Aguadas, Javier Ocampo López, recupera para mostrar que sí se tenía conciencia que los masones eran agentes de la vanguardia ideológica independentista: "Precisamente son los herejes de la impía secta de los francmasones, quienes han impulsado la revolución" y que, en palabras del sermón de José Antonio de Torres, es taxativo:

clase de hombres de la más detestable, y peores que quantos herejes, incrédulos y libertinos ha habido, ni jamás habrá, con sus patriarcas Wiclef, Wolter, Callostro, Rusó y los demás hermanos terribles, como ellos los llaman. Los francmasones como ángeles de la bestia han rodeado toda la tierra para derramar las redomas de la ira de Dios sobre los pueblos. ${ }^{23}$

Este documento, como tantos otros recuperados, demuestran que no se inventa la tradición de la influencia de los masones en el proceso de independencia. ${ }^{24}$ En la segunda, los turiferarios, se caracterizan por fraguar una visión preñada del mito

23. Antonio de Torres. “Oración Fúnebre”, citado por Javier Ocampo López. El proceso ideológico de la Emancipación (Medellín: UPTC/La Carreta, 2010), 237. (Se respetó la ortografía de los textos, con la grafía de la época, citados por el autor).

24. Al respecto, puede verse a Antonio de León (1816) con su “Discurso Político Moral sobre la obediencia debida...", donde manifiesta abiertamente el ataque a la masonería como proceso social: “¿Filósofos, petulantes, atrevidos, sanculotes y mazones iluminados; vosotros sí, vosotros únicamente sois los que propagáis tan locas ilusiones para engañar a los Pueblos incautos, y haceros sus tiranos y verdugos. (...) Debéis mirarlos como unos monstruos, declarados enemigos de la Religión y de la Sociedad, sin tratar con ellos, según el consejo del Apóstol, porque estos son Profetas Falsos..., citado por Javier Ocampo López (2010). El proceso ideológico de la emancipación, 237. 
de los orígenes, que buscan vincular la tradición masónica con una edad dorada, al inicio de los tiempos. Para el autor, César Vidal (2005), ${ }^{25}$ son doce los orígenes de la masonería generalmente aceptados. Los orígenes históricos de la masonería se entroncan así con las más antiguas tradiciones teúrgicas y esotéricas. De entrada, debe señalarse que no hay una opinión unánime al respecto. Las tesis más ortodoxas ubican el origen de la masonería en las Constituciones de Anderson (1717). Sin embargo, no hay una visión de consenso acerca de las raíces históricas de la masonería a lo largo de los siglos.

Para César Vidal (2005), se inicia con la religión patriarcal, los Antiguos misterios, el Templo de Salomón, los cruzados, los caballeros templarios, los colegios romanos de artífices, los rosacruces, Oliver Cromwell por razones políticas, el pretendiente de la restauración de la Casa de Estuardo, el trono británico, sir Christopher Wren, el Dr. Desaguliers y otros, en 1717.

Incluso una de esas tradiciones la entroncan con la teoría megalítica (que significa en griego gran piedra). Influenciada por la propuesta de los investigadores C. Knight y R. Lomas, para quienes el origen de la masonería habría que remontarlo a las tribus que durante la Prehistoria llevaron a cabo la construcción de los monumentos megalíticos y, de manera muy especial, a los druidas, quienes combinaron el dominio de la construcción y de la astronomía. Tal sería presuntamente el caso de Newgrange en el río Boyne y del famoso Stonehenge (England, 2 miles $(3 \mathrm{~km})$ West of Amesbury and 8 miles $(13 \mathrm{~km})$ North of Salisbury). Según estos autores, la masonería ya habría existido, por lo tanto, en un período de tiempo situado entre los años 7100 y 2500 a. C. Esa sabiduría concentrada en torno a observatorios astronómicos - la máquina de Uriel, por seguir el vocabulario de Knight y Lomas - se habría llevado a Oriente con anterioridad a un diluvio que asoló el planeta y que habría tenido lugar en torno al 3150 a. C. Semejante sabiduría se habría conservado a través de los sacerdotes judíos del Templo de Salomón. De allí precisamente la habrían recibido los templarios durante el siglo XII d. C.

De acuerdo con esta teoría, por lo tanto, el saber masónico se remontaría a la Prehistoria, ya se habría albergado en el seno de agrupaciones de sabios astrónomos que, antes del Diluvio Universal, la habrían pasado a Oriente. Esta es la peculiar explicación de los orígenes de la masonería, que se entroncaría con dos teorías: 1) aquellas que conectan el nacimiento de la masonería con la construcción del Templo de Salomón; y, 2) La teoría que ensambla su rigen con los caballeros templarios.

La teoría megalítica plantea problemas históricos de no escasa envergadura y más aún si se estudia su origen desde la historia de la teúrgia. Para Serge Raynaud de la Ferriére, las piedras druídicas son centros de magia y de simbología; la piedra

25. Cfr. César Vidal, Los masones: la historia de la sociedad secreta más poderosa del mundo (Barcelona: Planeta, 2005). 
central (la encina, Entidad vegetal), Piedra de Mundo, los dólmenes de base, las piedras de equilibrio, y el menhir.

Para Eduardo Callaey, ${ }^{\mathbf{2 6}}$ la tradición masónicatiene herencia delos constructores benedictinos del siglo XI, especialmente en lo que atañe a la tradición del uso del mandil, el mazo y el cincel.

En términos históricos, se diría que la tendencia turiferaria tiene interiorizado el mito de origen (Le Goff), ${ }^{27}$ como prolongación de los mitos cosmogónicos, ${ }^{28}$ y relatan cómo el mundo se ha modificado, para dar cuenta de los fenómenos del cosmos y sus implicaciones en los fenómenos sociales, políticos y económicos.

Y, en tercer lugar, la que a mi modo de ver se podría etiquetar como la visión de los dilettantes. En América Latina, esta visión ha tenido una marcada influencia. Al respecto, dice Ferrer Benemeli:

otra escala o categoría de escritores sobre la masonería son los que debido a las desviaciones e implicaciones socio-políticas que en algunos países del área latina adoptó cierta pseudomasonería en los siglos XIX y XX, se han dedicado a la literatura polémica, desprovista del más elemental sentido crítico e histórico, y que habría que calificar de pseudo historia panfletaria tan cultivada por ciertos autotes como Pierre Virion, Maurice Pinay, Mauricio Carcavilla, el marqués de Valdelomar, etc., por citar sólo algunos. ${ }^{29}$

Estas tendencias también pueden evidenciarse en la Historia de la Masonería en Venezuela; al respecto, señala Eloy Reverón, fundador de la primera cátedra de Historia de la Masonería en Venezuela, en la Escuela de Historia de la Universidad Central de Venezuela (UCV), que "Uno de los asuntos más delicados, al tratar temas sobre la Historia de la Masonería, es la falta de fundamentos y la poca seriedad en el manejo de las fuentes con que alegremente asume la historia de la Masonería mucha gente ajena al oficio de Historiador." ${ }^{30}$ El mismo Ferrer Benimeli, masonólogo reconocido, plantea que "cabría preguntarse si la presencia de la Masonería en Hispanoamérica es causa o más bien consecuencia de la independencia (...) Tan sólo consta de la presencia de algunas logias masónicas a finales del siglo XVIII, y por consiguiente anteriores al movimiento emancipador."31 Queda claro que no son excluyentes; puede ser causa en tanto la Ilustración es vital para la maduración ideológica de las elites independentistas. Es importante destacar que grandes masones fueron los redactores de las Constituciones en Venezuela y la Nueva Granada; en Venezuela, se destaca a Juan Germán Roscio

26. Eduardo Callaey, El mito de la revolución masónica. La verdad sobre los masones y la Revolución Francesa, los Iluminados y el origen de la masonería moderna (México: Lectorum, 2008).

27. Jacques Le Goff, El orden de la memoria. El tiempo como imaginario (Barcelona: Paidós, 1991).

28. Mircea Eliade, Lo sagrado y lo profano (Barcelona: Guadarrama/Punto Omega, 1981).

29. Ferrer Benimeli, Bibliografía de la masonería, 18.

30. Cfr. Mónica Correa, La masonería en el Zulia durante el siglo XIX, http://monicasonica.blogspot. com/2008/03/la-masonera-en-el-zulia-durante-el.html

31. José Ferrer. "Bolívar y la masonería”, Revista de Indias 172 (julio-diciembre 1983), 632. 
(1811) y, en la Nueva Granada, a Juan Nepomuceno Toscano, ${ }^{32}$ junto a Joaquín Umaña y Francisco de Jove Huergo. Y es consecuencia, en tanto el mismo proceso de independencia maceró en los colectivos históricos las ideas de la libertad, la igualdad y la fraternidad, de inspiración ilustrada y masónica.

Como quiera que fuese, algunos historiadores retoman la tradición y afirman que la presencia de la masonería en las costas de Venezuela se registra desde mediados del siglo XVIII, a tan solo diez años de la primera logia española. ${ }^{33}$

al menos desde 1738, la Francmasonería organizada trabajaba activamente frente a las costas de Venezuela actual, la Tierra Firme colonial, y de las islas del Caribe en posesión de España, sobre cuyas poblaciones, mediante la acción concluyente de sus comerciantes y contrabandistas, debieron proyectar intensa acción proselitista. ${ }^{34}$

Para contextualizar la presencia masónica en las colonias de España, se puede decir, siguiendo a Alfonso Fernández Cabrelli, que:

nos quedan dieciséis logias de las que tenemos noticias documentadas, actuando en nuestra América: del Pacífico al Atlántico, del Caribe al Plata. De cualquier manera, aun excluyendo de la cuenta, con exceso de rigor científico, los tres talleres denunciados ante la Inquisición (el de Jalapa, de la Ciudad de México, en formación; el de la costa de Pichi y el de Lima), parece que las doce logias restantes, - -acerca de cuya existencia no existe discusión-, son número más que suficiente para justificar (...) que puede sostenerse razonablemente que esa irrefutable, innegable presencia de tan abundantes manifestaciones de una masonería organizada en logias (...) Constituyen además, elementos de juicio muy atendibles que vienen a robustecer la tesis de quienes sostienen que la Institución Fraternal tuvo papel protagónico, no único pero sí de primer nivel, en la preparación de la opinión de las clases dirigentes y los estratos sociales más cultivados de Hispanoamérica a favor de la Independencia. ${ }^{35}$

Por su parte, el historiador chileno José Toribio Medina ${ }^{36}$ señala que la primera logia descubierta por la Iniciación en la América hispana es de 1773, en Lima. Al tomar en cuenta el inventario de Alfonso Fernández Cabrelli respecto a las logias masónicas, elevaron columnas en los siguientes países: 1) Cuba, 1763;

32. La Constitución de Tunja, del 9 de diciembre de 1811, debe su trabajo a estos ilustrados, en especial al masón Juan Nepomuceno Toscano. En la Convención de Ocaña, se constata públicamente la condición masónica de Juan Nepomuceno Toscano, al alinearse a los seguidores de Francisco de Paula Santander.

33. La primera logia en España data del 15 de febrero de 1728, en la madrileña calle de San Bernardo, por el Duque de Wharton, con el nombre de "Las Tres Flores de Lys". Esta logia, que también recibió el apelativo de la "Matritense", figura en los Registros oficiales de la Gran Logia de Inglaterra hasta 1768. Cfr. José Ferrer Benimeli, La Masonería Española en el Siglo XVIII (Madrid: Siglo XXI, 1986), 48-70.

34 Alfonso Fernández, La Francmasonería en la Independencia de Hispanoamérica (Montevideo: Ediciones América Una, 1988), 28

35. Fernández, 66-67.

36. José Toribio Medina. Historia de la Inquisición en Lima (Santiago de Chile: Fondo Histórico y Bibliográfico José Toribio Medina), 2, 314-20. 
2) Nicaragua, 1763; 3) Belice, 1763; 4) México, Ciudad de México, 1768; 5) México, Jalapa, 1768; 6) Lima, 1773; 7) Honduras, 1776; 8) Río de la Plata, Logia Independencia, 1795; 9) Río de la Plata, Logia San Juan de Jerusalén de la Felicidad, 1804; 10) Río de la Plata, Logia Estrella del Sur, 1806; 11) Santa Fe de Bogotá, la Logia de Nariño, 1794; entre otras. Lamentablemente, las logias masónicas en Venezuela, a pesar de la tradición reseñarlas como las primeras, al datar de 1738, no se hubieran documentado. A continuación, se presenta un poco el estado del arte de la historiografía masónica en Venezuela.

Entre los primeros trabajos acerca de la Historia de la Masonería en Venezuela, se cita a Asciclo Valdivieso Montaño ${ }^{37}$ y Celestino Romero, ${ }^{38}$ quienes piensan que en Venezuela la Masonería ya estaba presente antes de los movimientos independentistas, trabajos que, por cierto, no reseña José Ferrer Benimeli. ${ }^{39}$ Pero, al mismo tiempo, se encuentran los trabajos antimasónicos, como es el caso de Nicolás Navarro, La masonería y la independencia (Caracas, 1928), en la que el autor, un sacerdote, dedica un libro como ofrenda a la memoria de Bolívar en el Centenario de su Decreto de condena a la masonería (8 de noviembre de 1828), con lo que pretende demostrar que ni Bolívar ni Miranda fueron masones. ${ }^{40}$

La presencia documentada de presencia de masones en Venezuela es del año 1796, cuando llegaron a Venezuela varios prisioneros acusados de conspiración en contra de la Corona; los nombres de estos revolucionarios eran: Manuel Cortés y Campomanes, ${ }^{\mathbf{4 1}}$ Juan Mariano Picornel, ${ }^{\mathbf{4 2}}$ Juan Manzanares, ${ }^{43}$ José Lax ${ }^{44}$ Bernardo Garaza, Juan Pons Izquierdo, Joaquín Villalba y Sebastián Andrés, ${ }^{45}$ quienes

37. Cfr. Asciclo Valdivieso, Introducción a la Historia de la Masonería en Venezuela (Caracas: Tipografía Americana, 1928).

38. Celestino Romero, Raíz Histórica de la Masonería en Venezuela (Caracas: Empresa el Cojo, 1957). Este trabajo, de 127 p, presenta muestras de los predecesores de la masonería en Venezuela. Cfr. José María España, Manuel Gual, Miranda y Sacerdotes iniciados en la Logia de Carúpano.

39. Cfr. Ferrer, Bibliografía de la masonería, 1974.

40. Ferrer, Bibliografía, 1974, 82. Recomienda, además, para el estudio de la masonería en Sudamérica, los siguientes textos: G. Furlong y A. R. Geoghegan. Bibliografía de la revolución de mayo 1810-1828 (Buenos Aires: Biblioteca del Congreso, 1960); R. A. Humphreys y J. Lynch, eds., The origin of the Latin American Revolutions 1808-1826 (New York: A. Knopf, 1965); P. Leturia y M. Batllori, La primera misión pontificia a Hispanoamérica 1823-1825 (Ciudad del Vaticano: Biblioteca Apostólica vaticana, 1963); Jorge Pacheco Quintero, La masonería en la emancipación de América (Bogotá: La Gran Colombia, 1943); Carlos Restrepo Canal, "Informe sobre la masonería y la independencia", Boletín de Historia y Antigüedades (Bogotá, 1959); M. V. Lazcano, Las sociedades secretas, políticas y masónicas en Buenos Aires. (Buenos Aires: El Ateneo, 1927); Aurelio Miranda Álvarez, Historia documentada de la masonería en Cuba (La Habana, Molina, 1933); Félix Navarrete, La masonería en la historia y en las leyes de México (México: Jus, 1957); Carlos Nouel, Reseña histórica de la masonería en Santo Domingo (Ciudad Trujillo, 1949).

41 Aparece registrado su nombre como masón en el índice onomástico de Pepe Rodríguez, Masonería al descubierto (Del mito a la realidad 1100-2006) (Barcelona: Temas de hoy, 2006).

42. Cfr. José Ferrer, coord., Masonería, política y sociedad (Symposium de Metodología Aplicada a la Historia de la Masonería Española), (Zaragoza: Centro de Estudios Históricos de la Masonería Española, 1989); se hace un estudio sobre Juan Picornell y su formación masónica. Cfr. Román Piña, "Juan Picornell: de maestro reformista a líder revolucionario", 2, 587-98.

43. Aparece registrado su nombre en el índice onomástico de Rodríguez, Masonería al descubierto.

44. Ibíd.

45. Ibíd. 
participaron en la "Rebelión de San Blas" y enviaron a Venezuela para purgar la pena. Los venezolanos Manuel Gual Curbelo ${ }^{46}$ y José María España Rodríguez ${ }^{47}$ los conocieron y se familiarizaron con sus ideas, para luego ser iniciados como masones. Esta es la primera tesis sobre la propagación de la luz masónica en Venezuela. Sin embargo, no hay ningún testimonio fehaciente de sus iniciaciones, pero es comprensible que lo fuera así, por el carácter persecutorio que se tenía hacia la masonería. Por eso, se puede decir que, al recurrir a las mentalidades, como herramienta metodológica, el secreto masónico es un elemento que debe tenerse en cuenta como prueba mental y no solo física, como lo impone el positivismo. El purismo de los historiadores positivistas pide pruebas, que ni siquiera podían presentar los más consagrados masones, como es el caso de Miranda; imagínese en una sociedad en la que se perseguía políticamente a los masones y, además, el Santo Oficio tenía consagrados castigos ejemplarizantes a quienes fueran confesos masones.

\section{MIRANDA Y LA FRANCMASONERÍA}

Miranda nació en Caracas el 28 de marzo de 1750; era el hijo mayor de don Sebastián de Miranda y Ravelo, oriundo del Valle de Orotava, en Canarias, y doña Francisca Antonia Rodríguez Espinosa. Francisco (hijo) fue el primer nacido en Venezuela, por la rama paterna. El apellido Miranda tiene una raíz noble, de las más célebres de España, Portugal, e Italia. Incluso, por la línea italiana, su apellido se emparienta con los Duques de Miranda que, genealógicamente, tendrían cercanía con el autor de la Summa Teológica, Santo Tomás de Aquino. Por la línea de Portugal, se entronca con los nacidos en Goa, y de la tierra lusitana. En línea española, tienen su origen en Avellaneda, entre los que se cita a los Duques de Miranda y Duque de Peñaranda. Es célebre el antepasado jesuita llamado Francisco de Miranda, nacido en 1679 y muerto en 1744, catedrático de teología en Salamanca y Valladolid. Sin embargo, la casa de los Miranda más cercana a este Francisco Miranda está en Oviedo.

La heráldica familiar explica arquetípicamente la herencia galante de este Precursor, pues Melendo Analso de Miranda se caracterizó por su habilidad de

46. Cfr. Pedro Grases, La conspiración de Gual y España y el ideario de la independencia (3ㅜa ed., Caracas: Academia Nacional de la Historia, 1997), XV, 300 p. Allí señala los textos de la “Conspiración”: 1) Las "Ordenanzas", 2) La alocución, "Habitantes libres de la América Española”, 3) Las canciones para las masas: "La Canción americana" y la "Carmañola americana", 4) "Los Derechos del hombre y del ciudadano", con varias máximas republicanas y un discurso preliminar dirigido a los americanos. También puede verse: Héctor García Chuecos, Documentos relativos a la Revolución de Gual y España. (Caracas: Instituto Panamericano de Geografía e Historia, 1949), 219-29.

47. Aunque algunos sostienen que, desde 1794, la casa de José María España, en La Guaira, era una especie de "Logia Secreta", donde se reunían para informarse sobre los progresos de la Revolución Francesa. Esta analogía entre "Logia Secreta" y "Logia masónica" es el origen de términos posteriores como Sociedad patriótica o sociedad secreta, lo cual permite trazar una línea de continuidad que evidencia la presencia de masones en la independencia. Incluso se documenta que Juan Manuel Picornell asistió a una sesión en la Sociedad Patriótica y asesoró en la redacción del Acta de la Independencia, en 1811. 
donjuanismo, enriqueció el blasón de armas al libertar en sangrienta pelea con los moros a cinco doncellas, que llevaban a Córdoba como esclavas.

Estudió en la antigua Real y Pontificia Universidad de Caracas, a la que ingresó en 1764. Eran tiempos cuando se comenzaba a vivir la diatriba ideológica en la Universidad de Caracas; por un lado, el paradigma decadente aristotélico-tomista $y$, por otro, la emergencia del paradigma inductivo-experimental fundado en la física newtoniana. La lucha ideológica entre los rancios criterios inspirados en el Paradigma aristotélico-tomista y el emergente Paradigma Educativo de la Ilustración no solo fue de palabra, sino tuvo implicaciones de jure; al respecto, se cita la polémica del padre A. Valberde, en 1770, quien señalaba que "1) La filosofía de Aristóteles, ni para el conocimiento de la naturaleza, ni para tratar la sagrada teología es útil, sino perniciosa; y 2) que Santo Tomás floreció en los siglos de la ignorancia".48 Pero quizá el caso que tuvo mayor estelaridad fue el de Baltasar de los Reyes Marrero, ${ }^{49}$ profesor de la cátedra de Filosofía en la Real y Pontificia Universidad de Caracas, justamente porque "no enseñaba la filosofía de Aristóteles sino la moderna doctrina de Newton, Paracelso." La resistencia al cambio aquí no venía de la oficialidad, sino de uno de los padres o representantes, específicamente del Dr. Cayetano Montenegro. El rector Juan Agustín de la Torre, del bienio 17891791, se pronuncia en el juicio a favor de Baltasar de los Reyes Marrero y alega que: "ninguna nación ha hecho progresos de consecuencia por las armas, por las artes, agricultura y comercio, hasta que se ha entregado al indispensable cultivo de las ciencias", 50 respuesta que estaba en consonancia con su criterio acerca de los cambios que debía experimentar la educación.

Este es el ambiente intelectual donde abre los ojos del entendimiento el joven Francisco, entre las polémicas de la tradición conservadora, rancia, y apegada al estilo medieval, y la emergencia de las ideas de la modernidad. En 1771, se embarca a España para continuar su formación en las milicias del Rey, donde estudió matemática e idiomas, para llegar a dominar cinco, además del griego y el latín. Su carrera militar la inició temprano; en 1772, entró como Capitán del Regimiento de Infantería de la Princesa; luego, lo enviaron a África a luchar bajo la bandera de Carlos III; allí permaneció por tres meses y demostró su arrojo en batalla contra los moros. Su carrera militar la realizará posteriormente al transferirlo como capitán del Regimiento de Aragón, que se envió al Nuevo Mundo bajo el mando del mariscal Victoriano de Navia. Sale de Cádiz en 1780, realiza andanzas por las Antillas, Cuba y el Gobernador de Luisiana. Por sus servicios, lo asciende a teniente coronel el Gobernador Cagigal, al tener una destacada participación en las batallas que sellaron el triunfo de la Independencia Norteamericana, por su

48. Rafael Fernández Heres, Memoria de cien años (Caracas: Ediciones de la Presidencia de la República, 1981), $1,47$.

49. José Pascual Mora García, "Baltasar de los Reyes Marrero (1752-1809): primer educador de la enseñanza de la física moderna en la Universidad de Caracas (últimas décadas del siglo XVIII) (para una historia conectada de la historia de la educación en Colombia y Venezuela). Revista Historia de la Educación Latinoamérica 13 (2009).

50. Mora García, Ob. cit., p. 100. (Extracto del Discurso Económico del Dr. Juan Agustín de la Torre). 
apoyo a George Washington en Yorktown. A partir de 1784, se lo encuentra en Londres, donde conoce a Jeremías Bentham, quien es uno de los padres de la teoría económica clásica.

La amistad entre Francisco de Miranda y Bentham tiene interés en el desarrollo no solo de sus ideas, sino por su impacto en la educación durante la Gran Colombia. Poco antes de la publicación de los Principios de Legislación (1802), se habían conocido en Londres. La primera carta que lo constata es del año 1798; un diplomático del Zar los había presentado. La amistad del venezolano y Bentham tiene gran interés en la biografía intelectual del filósofo inglés; en primer lugar, porque Miranda era gran amigo del historiador escocés James Mill; juntos iban a escribir, en 1808, un artículo en defensa de la emancipación de las colonias españolas en América, en la Edinburgh Review. Francisco de Miranda hace que Bentham y Mill se conocieran en 1809. Y, en segundo lugar, Bentham, tras algunos años de reacción antidemocrática inducida por los excesos de la revolución francesa, volvía a la actitud democrática, en la que se iba a mantener toda la vida; sin duda, el anti-colonialismo de Miranda contribuyó a la evolución democrática de Bentham.

Miranda planeó su segunda expedición a las costas de Venezuela, y Bentham preparó una serie de manuscritos, entre los que destacan: esbozos de Código Constitucional, de Ley de Prensa, de Código Civil, algunos de los cuales entregó para su traducción al joven Andrés Bello. La aventura de Miranda se malogró y los textos que preparaba germinaron en la mente de Bentham, hasta convertirse en su magna obra inconclusa, el Código Constitucional; de manera que Miranda fue fundamental en la creación del filósofo inglés.

Los primeros ecos del pensamiento benthamiano en Latinoamérica aparecieron en El Español, que era una revista mensual publicada por José María Blanco White, con apoyo financiero del Foreign Office, de 1810 a 1814. Tuvo amplia difusión en América y en ella presentó Blanco White a sus lectores noticias sobre los trabajos de Bentham en materia de procedimiento parlamentario, de libertad de prensa, de teoría del derecho penal y de organización colonial. Es posible que fuera la fuente donde primero se leyó el pensamiento de Bentham en Venezuela y la Gran Colombia.

Las ideas de Bentham tuvieron gran repercusión en la Nueva Granada, ${ }^{51}$ al ser propuesto su modelo en la Universidad Republicana (1826) por Francisco de Paula Santander. El punto de partida, así como la temática principal de Bentham en casi todas sus obras, lo constituye el llamado principio de utilidad. A cada paso apela a él y lo presenta como principio general de toda su filosofía moral, social y política. No fue el primero en invocar tal criterio, como dirá más tarde Stuart Mill, pues lo

51. Cfr. Carlos Barrera Martínez, La historia de las ideas benthamistas y antibenthamistas en Boyacá (Tunja: Academia Boyacense de Historia, 2010), 200. Merece un reconocimiento especial el trabajo de Barrera Martínez, sobre todo por su dedicación a revisar la influencia sobre la elite intelectual neogranadina y, en especial, la boyacense de las ideas liberales de Bentham. No es casualidad que el padre del liberalismo colombiano sea Ezequiel Rojas (1803-1873), que llama el "benthamista mayor". 
hicieron los numerosos escritores que desde Epicuro a Bentham sostuvieron la teoría de la utilidad. El mérito de Bentham como fundador del utilitarismo está en haber pretendido construir la ciencia moral y política sobre la base meramente empírica y según el método positivo, similar al de Comte. La ciencia debe apoyarse en hechos y, en el dominio moral y social, los únicos hechos en que es posible apoyarse son el placer y el dolor. Por ellos se determina la conducta del hombre, como único motivo posible de acción.

El utilitarismo de Bentham causó polémicas radicales en Bogotá, hasta el punto que el Libertador solicita se suprimiera la lectura de la obra de Bentham en la Universidad. El clero, representado por el doctor Francisco Margallo, atacó las políticas educativas del Vicepresidente Santander, por haber facilitado la introducción de las doctrinas benthamistas en las universidades. La Iglesia Católica consideró que el liberalismo y la masonería, defensores de las tesis de Jeremías Bentham en las universidades, eran los enemigos del orden tradicional. Así mismo, consideraron que el Plan de educación de Santander afectaba el monopolio de la educación por parte de la Iglesia, en un momento en que sus relaciones con el Estado no eran las mejores. La Reforma Educativa de Santander entró en el problema de las malas relaciones entre la Iglesia y el Estado.

La personalidad sobre quien recae con mayor fuerza la proyección de la masonería en Venezuela, el Caribe y las colonias españolas en América es Francisco de Miranda. ${ }^{52}$ En relación con Miranda, no es menos polémica su vinculación con la masonería; respecto a su vocación masónica, ${ }^{53}$ dos vertientes se disputan tesis antagónicas: la primera sostiene que Miranda fue masón y que se inició, según la tradición, en 1783 en Filadelfia; esta tesis la sostienen Américo Carnicelli, ${ }^{54}$ Patricio Maguire ${ }^{55}$ y Juan Canter. ${ }^{56}$ Según esta tradición, a Miranda se le atribuye, igualmente, la introducción de la Francmasonería Progresista a la América española, al ser miembro del Supremo Consejo de París y fundador de varias logias en el continente europeo, pero lo trascendental no es que fuera masón, sino haber iniciado a los principales ideólogos de la independencia en la logia Lautaro, que funcionaba en Cádiz, España; entre ellos: Simón Bolívar, José de San Martín, Bernardo 0’Higgins y muchos de los más notables próceres de la independencia suramericana. Entre los historiadores más reconocidos de la masonería, quizá el trabajo más relevante en adelantar una investigación más convincente sobre

52. Cfr. Robert Arapé, “¿Fue masón Miranda?”, en Luis Cañón, coord., Miranda. El visionario (Caracas: Panorama-Pdvsa, 2006), 35. El autor sostiene que Miranda nunca fue masón.

53. Cfr. Edgar Perramón, Breve Historia de la Masonería en Venezuela (Caracas: Talleres tipográficos Cultural. 1997).

54. Cfr. Américo Carnicelli, La Masonería en la Independencia de América (Bogotá: Artes Gráficas, 1970), 2 volúmenes.

55. Cfr. Patricio Maguire, La masonería y la emancipación del Río de la Plata (Buenos Aires: Santiago Apóstol, 2000).

56. Cfr. Juan Canter, Las Sociedades Secretas, políticas y literarias (Buenos Aires: Imprenta de la Universidad, 1942). 
la vocación masónica de Miranda es el trabajo del uruguayo Alfonso Fernández Cabrelli. ${ }^{57}$

Pocos historiadores de oficio apoyan y creen en esta tesis, entre ellos el colombiano, Indalecio Liévano Aguirre; ${ }^{58}$ el venezolano, Agustín Mijares; ${ }^{59}$ y el ecuatoriano, Alfonso Rumazo González. ${ }^{60}$ Por cierto, Rumazo González afirma de manera más taxativa el compromiso masónico de Miranda; al respecto señala:

El secreto y el juramento constituyeron el factor sine qua non de la emancipación americana, presentes como estaban en las colonias tanto la estricta y cruel vigilancia de las autoridades españolas, como la actividad de la Inquisición. Sólo el secreto de la conspiración y la consiguiente coordinación entre los revolucionarios, secreta asimismo, pudieron conducir al éxito final de la conspiración. Miranda, iniciado ahora en Gibraltar, utilizará el poderío masónico en forma extraordinaria; y todos los capitanes que con él conspiraron ${ }^{61}$.

La verdad histórica, al parecer, no logra presentar con pruebas positivas la vocación masónica de Miranda, pero se debe decir, en descargo, que no son suficientes las apreciaciones de que no existen documentos para negar su filiación con la Masonería, pues, en el sentido estricto, Miranda pudo ser fiel a su juramento de no revelar su condición.

La segunda vertiente sobre el supuesto compromiso masónico de Miranda sostiene decididamente que Miranda no fue masón. ${ }^{62}$ Los historiadores de oficio más reconocidos sobre el tema Miranda no reconocen la iniciación masónica del Precursor. El Hermano Nectario María, ${ }^{63}$ por su parte, en su interesante investigación tampoco afirma nada al respecto, ni siquiera contrastando su Acta de Defunción, donde algunos ${ }^{64}$ sostenían que Miranda se había negado a

57. Alonso Fernández, La Francmasonería en la Independencia de Hispanoamérica (Montevideo: Ediciones América Una, 1988).

58. Cfr. Indalecio Liévano, Bolívar. (Bogotá: Editorial Prensa, 1981).

59. Cfr. Augusto Mijares, El Libertador (Caracas: Ediciones de la Presidencia de la República/Academia Nacional de la Historia, 1987).

60. Cfr. Alfonso Rumazo, Francisco de Miranda (Barquisimeto: Universidad Centroccidental Lisandro Alvarado, 2006).

61. Ibíd., p. 37.

62. La tesis de esta vertiente se le atribuye a Jules Mancini, de quien dice Eloy Reverón: "Veremos más adelante cómo la pródiga imaginación de Mancini convierte a estas Juntas en logias masónicas, y a Francisco de Miranda en una suerte de Gran Maestro de la Emancipación” (Cfr. Eloy Reverón, “¿Cómo se originó la creencia de que Miranda fue masón?", http://masoneriamirandina.blogspot.com. Agrega Reverón que "Miranda fue reconocido oficialmente como masón en el año 1950. El doctor José Tomás Uzcátegui emitió un decreto cuando ocupaba el cargo de Gran Maestro con el objeto de ubicar y publicar los documentos que lo vincularon a la Orden. Después de cincuenta y ocho años, los buscados documentos brillan por su ausencia." También se hace eco de Mancini Erminy Arismendi, quien publica: "Influencia de la Masonería en la Libertad de América" en: Gaceta Masónica 1, n¹8 (24 de marzo de 1928), 1.

63. Cfr. Hermano Nectario María. La verdad sobre Miranda en La Carraca (Madrid: Imprenta Juan Bravo, 1964).

64. Ricardo Becerra, Ensayo histórico documental de la vida de don Francisco de Miranda, citado por el Hermano Nectario María, La verdad sobre Miranda en La Carraca, 109. 
recibir la Extremaunción. Al respecto, Nectario María afirma: “Todo esto es mera falsedad y mentira urdida por un tal Manuel Sauri, marino peruano, quien (...) refería al señor Ricardo Becerra haber acompañado a Miranda en La Carraca",65 y fundamentan esta tesis con el criterio de no haberse encontrado categóricamente un solo documento de alguna logia en EEUU, España o Inglaterra.

Sin embargo, si se toma como cierta la tesis de los historiadores de las mentalidades, según la cual nada revela más lo que piensan los hombres sino los libros que lee y posee, entonces debería reportar su biblioteca algo de información acerca de su masonería. Pues bien, de los casi siete mil volúmenes de su biblioteca que se remataron, ${ }^{66}$ una inmensa mayoría son obras de filósofos y literatos masones. Y esta sí es una clave cierta. De hecho, los filósofos francmasones del siglo XVIII no registran entre sus obras que tratasen directamente el tema, si es dable atenerse a la rigurosa revisión bibliográfica de José Ferrer Benimeli, reconocido mundialmente como el mejor expositor de la bibliografía masónica, que no cita a ninguna obra de los filósofos clásicos del siglo XVIII que fueran masones.

Para recapitular, se dirá que la leyenda dorada de la masonería en Venezuela descansa sobre dos pivotes: uno, que la llevaron a Venezuela los responsables de la Rebelión de San Blas; y, dos, que Miranda fue el responsable, por tener el grado simbólico y la autorización del Oriente de Londres y Francia para realizar las iniciaciones de los prohombres más importantes de la independencia, pero esta segunda tesis no es concluyente, pues los historiadores más reconocidos sobre el tema mirandino tampoco dicen nada sobre la iniciación en la masonería del Precursor; ni Mariano Picón Salas, ${ }^{67}$ ni Tomás Polanco Alcántara, ${ }^{68}$ ni Alfredo Boulton, ${ }^{69}$ ni J. L. Salcedo Bastardo, ${ }^{70}$ ni los trabajos más recientes de Carmen Bohórquez, ${ }^{71}$ y Manuel Hernández González. ${ }^{72}$ Es más sencillo presentar el compromiso masónico de Bolívar, pues se encontró su certificado de Compagnon reseñado por insignes historiadores como Manuel Pérez Vila, ${ }^{73}$ y Ramón Díaz Sánchez. Lo que sí se puede afirmar es que Miranda es el más reconocido por la

65. Nectario María, La verdad sobre..., 109.

66. En Londres, la biblioteca se remató en dos subastas: la primera, el 22 de julio de 1828, y, la segunda, el 20 de abril de 1833. Pero debido a que el Museo Británico conservó el Catálogo, el investigador Pedro Grases pudo rescatar ese documento. Cfr. Tomás Polanco, Conferencia leída en el Aula Militar de Cultura del Gobierno Militar de Cádiz, el día 17 de agosto de 1973, cuando era Embajador de Venezuela.

67. Cfr. Mariano Picón, Miranda (Caracas: Monte Ávila, 1997).

68. Cfr. Tomás Polanco, Tomás. Conferencia leída en el Aula Militar de Cultura del Gobierno Militar de Cádiz, el día 17 de agosto de 1973, cuando era Embajador de Venezuela.

69. Cfr. Alfredo Boulton, Miranda, Bolívar y Sucre, tres estudios iconográficos (Caracas: Italgráfica, 1959).

70. Cfr. José Salcedo, Miranda 1781-1981 (Caracas: Italgráfica, 1981).

71. Cfr. Carmen Bohórquez, Francisco de Miranda. Precursor de las independencias de la América Latina (Caracas: Universidad Católica Andrés Bello/Universidad del Zulia, 2002).

72. Cfr. Manuel Hernández, Francisco de Miranda y Canarias (Santa Cruz de Tenerife, Idea, 2007).

73. Cfr, Manuel Pérez Vila, "La experiencia masónica de Bolívar en París", en Visión diversa de Bolívar. (Ciclo de Conferencias en homenaje al Libertador con motivo del bicentenario de su natalicio). Caracas: Pequiven. 11 de mayo de 1983. 
tradición masónica como el pionero en levantar columnas de esa tradición en Hispanoamérica.

\section{JOSÉ CELESTINO MUTIS ${ }^{74}$ Y LA MASONERÍA EN LA NUEVA GRANADA}

Desde el punto de vista epistemológico, se precisan, de entrada, algunas de las categorías básicas de este estudio: logias masónicas, sociedades paramasónicas, sociedades patrióticas, entre otras. El propio José Celestino Mutis formó parte de los Novatores, ${ }^{75}$

en Sevilla funcionaba un grupo de Novatores, organizado por la regia Sociedad Sevillana, asociación muy combatida desde los claustros de la Universidad. Uno de los miembros de aquella agrupación, el médico Pedro Fernández de Castilla, fue el superior que vigiló los dos años de práctica médica de Mutis en el Real Hospital de la Marina de Cádiz. Es casi seguro que él fue el encargado de impregnarlo con las ideas de la renovación, pues no queda duda que Mutis compartía las opiniones de los Novatores, y era, a su modo, un producto de ellas ${ }^{76}$.

Esta sociedad filosófica y científica reunía un grupo de pensadores, entre los que sobresale Benito Jerónimo Feijoo ${ }^{77}$. Seguramente el espíritu que lleva a Mutis a organizar las Sociedades de Amigos del País y las tertulias se inspiraron en las prácticas de los Novatores.

74. “Había nacido Mutis en Cádiz el 6 de abril de 1732; procedía de una familia burguesa, lo cual le permitió educarse sin ningún contratiempo en un ambiente netamente ilustrado; comenzó sus estudios de gramática y filosofía en su ciudad natal y allí, en el colegio de San Fernando, inició la carrera de medicina, la que continuó en 1749 en el Real Colegio de Cirugía de Cádiz, dirigido entonces por Pedro Virgili; estos estudios los complementó con otros recibidos en Sevilla en la Universidad Hispalense, donde obtuvo los títulos de Bachiller, tanto en Artes y Filosofía como en Medicina." José Antonio Ferrer Benimeli, "Aproximación a la historiografía de la masonería latinoamericana", Rehmlac $4, \mathrm{n}^{\circ} 1$ (mayo-nov., 2012), 119.

75. "El movimiento novator se inicia fuera de la Universidad, en el seno de grupos laicos y eclesiásticos interesados por la filosofía natural y por la física en particular. En Medicina es donde se dan más claramente estos casos de innovación. En Zaragoza, bajo la influencia del italiano Juanini y Casalete y en Valencia, Crisóstomo Martínez. Otro médico, en los años ochenta, Luis Aldrete, con títulos como "Luz de la medicina" o "Crisol de la verdad", ridiculiza a las autoridades en filosofía y demuestra conocer a Descartes y Gassendi. Menos clara es la aportación de Isaac Cardoso ("Philosophia libera"), en contra de lo que se viene afirmando tradicionalmente, pues no recoge los vientos del conocimiento experimental, habla de la libertad, pero dentro de la tradición ecléctica humanista. De forma paulatina aparece una corriente que rompe con la ciencia dogmática universitaria (escolástica) y la erudición ecléctica humanista. En esta línea se encuentra Juan de Cabriada ("Carta philosóphica médico chymica"), quien prefiere las misceláneas científicas inglesas o alemanas antes que los discursos de las aulas, "en lugar de la agudeza y seguridad silogística o de la abrumadora erudición, aprecia la vigilancia y constancia en la observación de los fenómenos naturales” (p. 26). Algo más tarde, un grupo de médicos se considera deudor de sus ideas en Sevilla. Estamos hablando de la "Veneranda Tertulia Hispalense, Sociedad Médico-Química, Anatómica y Matemática", donde sobresalen: Muñoz y Peralta, Melero, Flores, y Ordóñez De la Barrera." Juan Diego Mata Marchena, "Una visión del siglo XVIII español", Cuadernos sobre Vico 13-14 (2001-2002), 372.

76. Gonzalo España, Mutis y la Expedición Botánica. (Bogotá: Panamericana, 1999), 16-17.

77. José Ferrer Benimeli, "Feijoo y la masonería”, en II Simposio sobre el Padre Feijoo y su siglo (Oviedo: Centro de Estudios del siglo XVIII, 1983), 2, 349-62. 
En el siglo XVIII, el espacio conceptual entre masonería o Sociedades Secretas o Sociedades de Amigos es muy tenue, incluso en algunos casos intercambiable. Recuérdese que la masonería ortodoxa nace en 1717 con los landmarks, adscrita al Gran Oriente del Rito Escocés Antiguo y Aceptado, pero, también, hay masonería adogmática, normalmente alineada con el Gran Oriente de Francia ${ }^{78}$. De manera que se debe alertar que la línea conceptual entre masonería y Sociedades Secretas no fue muy clara, incluso "la línea divisoria entre masonería y sociedades secretas, particularmente en el periodo que va de 1815 hasta 1830, tiende a ser difusa"; 79 en algunos casos, fueron intercambiables los términos de comuneros, carbonarios, jansenistas, ${ }^{\mathbf{8 0}}$ y masones; "sinónimo de jansenismo, la masonería fue un arma de ataque contra el incipiente liberalismo peninsular"81.

En esta arqueología del pensamiento paramasónico de Celestino Mutis, se dedicará un apartado al compartir con Diana Soto Arango la pregunta: ¿Mutis jansenista? ${ }^{82}$

El Jansenismo es un pensamiento heterodoxo, que se debe a Cornelio Jansen (1585-1658) y, en el caso de Mutis, se considera pionero de la filosofía natural en la Nueva Granada, incluso su tratamiento científico con la investigación botánica es casi panteísta: "estudiar la naturaleza es lo mismo que dirigirse a conocer las obras maravillosas de aquel Soberano Creador, que se deja conocer en parte por las cosas visibles." ${ }^{83}$ Obsérvese un detalle que pudiera pasar desapercibido: no es común dirigirse a Dios con utilización del concepto de Soberano Creador, y los masones hablan de Arquitecto del Universo. Elementos para la pesquisa conceptual. Luego de una laboriosa disquisición del término jansenista, Diana Soto Arango toma distancia de la calificación automática de aplicar el término jansenista a Mutis, pero sí acepta una posición intermedia, vinculada al regalismo y galicanismo: "de lo que se ha venido diciendo, puede deducirse que una interpretación del término jansenista en la España del siglo XVIII es la de hacerlo equivalente a regalismo y galicanismo; creemos que en este sentido se explica el jansenismo de Mutis." ${ }^{14} \mathrm{El}$

78. André Combes, Les trois siécles de la Franc-maçonnerie Française (París, Éditions Dervy, 2007). En mi visita al Gran Oriente de Francia, el 1 de septiembre de 2008, pude tener una entrevista con el Grand Secrétaire d'Affaires Internationales, a fin de recibir más información sobre la tradición masónica francófona.

79. Felipe Santiago del Solar Guajardo (2012) "Secreto y sociedades secretas en la crisis del Antiguo Régimen. Reflexiones para una historia interconectada en el mundo hispánico", Rehmlac 3, n 2 (dic. 2011-abril 2012), 138.

80. Del Solar, Ibíd. El exjesuita Lorenzo de Hervás y Panduro llega incluso a señalar que la crisis del Antiguo Régimen se debió a "sectas que impulsaron la revolución: el jansenismo, los filósofos, el calvinismo y la masonería", 146.

81. Del Solar Guajardo, "Secreto y sociedades secretas...,146.

82. Diana Soto Arango, Mutis, educador de la elite neogranadina (Tunja: Rudecolombia/UPTC, 2005), 29.

83. José Celestino Mutis, "Documentos sobre el sistema copernicano", en Revista Correo de Los Andes 21, (sept.-oct., 1981), 62. Citado por Soto Arango, Mutis, educador de la elite neogranadina, 28.

84. Soto Arango, Mutis, educador de la elite neogranadina, 33. 
galicanismo ${ }^{85}$ buscaba desconocer el poder del Papa, mientras que el regalismo se refería a una preeminencia del rey sobre los postulados papales.

Incluso Carlos III propició la política regalista, con el llamado Regio Exequátur, según el cual las bulas, para que tuvieran validez, debían tener permiso real. En efecto, Mutis, en la polémica con los dominicos, en 1774, en contra de la Inquisición romana, se pronuncia a favor del rey y en contra de Roma: "el logro de las reales justas intenciones de nuestro Católico monarca que con inimitable anhelo solicita mejorar las enseñanzas desterrando los abusos hasta ahora venerados, y establecer un método provechoso para la Ilustración de sus vasallos, a que nada se opone tanto, como la conducta observada por la Universidad Tomista."86

Recuérdese que una de las luchas de la masonería y el libre pensamiento fue deslindar el poder teológico del poder político, ya que ambos se imbricaban; esta es otra variante que apostaba a esa idea ilustrada y que fue punto de honor en las nuevas reivindicaciones políticas nacidas en el proceso de independencia. Lo cierto es que Mutis contribuye a la diseminación del espíritu de una época, a construir ese "utillaje mental", hasta que pueda anclarse en la cotidianidad.

La mentalidad se mide por la cotidianidad; con Jacques Le Goff (1980), se dice: "el nivel de la historia de las mentalidades es el de lo cotidiano (...) lo que escapa a los sujetos individuales de la historia porque es revelador del contenido impersonal de su pensamiento." ${ }^{87}$ En el momento en que llega a los sectores populares, se ensambla el imaginario colectivo, y el trabajo de formador de generaciones fue determinante. Le Goff (1991), representante de la tercera generación de Annales, es uno de los historiadores que más obras ha dedicado a estudiar la mentalidad; puntualiza que la memoria es uno de los objetos de la historia: "así como el pasado no es la historia, sino su objeto, la memoria no es la historia, sino al mismo tiempo uno de sus objetos y un nivel elemental de elaboración histórica." ${ }^{88}$ En su obra, despliega una batería de conceptos sobre la Memoria Colectiva, que son importantes para abordar el tema de la influencia de la masonería en la memoria colectiva de la época, entre los que cabe citar: "La memoria (...) no es una propiedad de la inteligencia sino la base, cualquiera que sea, sobre la que se registran los actos." ${ }^{89} \mathrm{Y}$, en este sentido, la memoria se convierte en un campo de la interdisciplina, de vital importancia para intentar comprender su alcance; por eso:

La memoria, como capacidad de conservar determinadas informaciones remite ante todo a un complejo de funciones psíquicas, con el auxilio de las cuales

85. "En cuanto al galicanismo, debe recordarse que en 1682 los obispos de Francia proclamaron los principios del galicanismo." Soto Arango, Mutis, educador de la elite neogranadina, 33.

86. Archivo general de Indias (AGI): "Testimonio de lo actuado sobre representaciones. Mutis, 11 de julio de 1774" Sección Quinta: Audiencia de Santa Fe, documento No. 20. F. 6. En Soto Arango, Mutis, educador de la elite neogranadina, 35 .

87. Jacques Le Goff, "La historia de las mentalidades, una historia ambigua”, en Jacques Le Goff y Pierre Nora. Hacer la historia (Barcelona: Laia, 1980), 3, 85.

88. Jacques Le Goff, El Orden de la memoria (Barcelona: Paidós, 1991), 50-51.

89. Ibíd., 49. 
el hombre está en condiciones de actualizar impresiones o informaciones pasadas, que él se imagina como pasadas. Bajo este aspecto, el estudio de la memoria penetra en la psicología, en la parapsicología, en la neurofisiología, en la biología y, para las perturbaciones de la memoria —en las que la principal es la amnesia-, en la psiquiatría. ${ }^{90}$

La memoria, además, es un instrumento del poder; apoderarse de la memoria es una de las máximas preocupaciones de las clases que han dominado y dominan las sociedades históricas. El estudio de la memoria es uno de los modos fundamentales para afrontar los problemas del tiempo y de la historia; cada momento histórico tiene sus medios para hacerlo; en el siglo XVIII, la Iglesia fue el gran gendarme de la memoria colectiva y, por eso, se buscó a toda costa deslindar el determinismo del papado en la cotidianidad de los hombres. No es fácil el trabajo del historiador de las mentalidades, pues tiene que ser a ratos psicólogo; Le Goff (1980) la describe como una actividad

que persigue en las aguas turbias de la marginalidad, de la anormalidad, de la patología social. La mentalidad parece revelarse de preferencia en el dominio de lo irracional y de lo extravagante (...) De ahí, cuando el historiador de las mentalidades pone su atención en sentimientos comunes o grupos sociales integrados, su elección voluntaria de temas límites (las actitudes frente al milagro o la muerte) o de categorías incipientes ${ }^{\mathbf{9 1}}$.

Así pues, se ve que, para hurgar en la memoria colectiva, se tiene que romper con los enfoques unidimensionales y las parcelas, al proyectar la investigación histórica en la visión interdisciplinaria. La Escuela de los Annales planteó "una historia cuya investigación se extiende a las dimensiones de todas las ciencias del hombre, a la globalidad de las citadas ciencias del hombre, y que, en cierto modo, se apoderaron de ellas para construir sus propios métodos y su verdadero dominio"92.

Este especial cuidado y vigilancia epistemológica que recomendaba Gaston Bachelard ${ }^{93}$ es clave en el estudio. Hay etiquetas que son simplistas y no se pretende reducir el pensamiento de un pensador tan enciclopédico como Mutis a una categoría, pero sí es conveniente desmitificar algunos enfoques iconoclastas de la masonería que han estigmatizado el aporte de las ideas masónicas para el avance de la ciencia. Por otra parte, es conveniente tener en cuenta el sentido histórico de los conceptos; lo que hoy se entiende académicamente como masonería no es lo que se entendía en el siglo XVIII o XIX; existen matices que develar, y de eso se trata. Sería un anacronismo histórico comprometer los conceptos que hoy se manejan para aplicarlos al estudio de la época. De hecho, la masonería no

90. Ibíd., 131.

91. Jacques Le Goff, J. Las Mentalidades. Una Historia Ambigua. En Le Goff, y Nora, comps., Hacer la historia, (Barcelona: Laia, 1980), 3, 90-91.

92. Fernand Braudel, Escritos sobre Historia, (México: FCE, 1991), 21.

93. Gaston Bachelard. El Nuevo Espíritu Científico (2ª ed., México: Nueva Imagen, 1985). 
funcionaba necesariamente en el siglo XVIII como una Sociedad Secreta, sino una sociedad con secretos. ${ }^{94}$

No obstante, por razones del rigor científico, se proponen unas apreciaciones conceptuales sobre logias masónicas, paramasónicas, Sociedades Secretas, Sociedades Patrióticas, entre otras. Las logias masónicas son

asociaciones de individuos que se dan tratamiento de hermanos y se procuran muto socorro. Son iniciáticas. Sus miembros realizan juramentos que los obligan. Poseen conocimientos esotéricos, en el sentido de que sólo pueden ser conocidos por sus miembros, de acuerdo con la estructura jerárquica de los grados, que varían según el rito en que se trabaje (...) Tienen fines filosóficos y filantrópicos y, de acuerdo con las Constituciones de Anderson, no permiten las discusiones políticas ni religiosas al interior de los talleres ${ }^{95}$.

Habría que agregar que pueden ser regulares o irregulares, según se encuentren alineadas, bien sea a la obediencia del Rito Escocés Antiguo y Aceptado o al Rito del Gran Oriente de Francia.

La sociedades paramasónicas no se sujetan a ningún oriente u obediencia y, al seguir a Carlos Francisco Martínez, Irene Castells, Jordi Roca Vernet y María Eugenia Vázquez, son aquellas que "incorporan elementos masónicos, ya sea materiales, consuetudinarios, lingüísticos, normativos o estructurales, pero con usos, finalidades y significados distintos a los masónicos"96. En el caso que se trabaja, son organizaciones para el avance de la ciencia y las ideas políticas.

La historiografía oficial ha negado el rol de la masonería como institución que intervino en la formación de los ideólogos de la independencia; aunque hay posiciones encontradas, se debe reconocer que en los últimos años hay una tendencia revisionista que está realizando nuevas lecturas. Los libros que han circulado sobre los bicentenarios en América Latina son una evidencia, pero va a tomarse en particular a Colombia. La mayoría de los trabajos tradicionales, al referirse a la participación de los ideólogos neogranadinos en la masonería, invocaban la obra de Américo Carnicelli ${ }^{97}$ y, acto seguido, agregaban, ¡no presenta pruebas! Como si se tratara de un tribunal. Esta apreciación permitía develar que

94. Yván Pozuelo Andrés, “La masonería: ¿Una organización discreta?”, Rehmlac 1, n 2 (dic. 2009-abril 2010), 62-87. Citado por Felipe Santiago del Solar Guajardo, "Secreto y sociedades secretas en la crisis del Antiguo Régimen. Reflexiones para una historia interconectada en el mundo hispánico”, Rehmlac 3, $\mathrm{n}^{\circ} 2$ (dic. 2011-abril 2012), 139.

95. María Eugenia Vázquez Semadeni, “La masonería en México, entre las sociedades secretes y patrióticas (1813-1830)", Rehmlac 2, n² 2 (dic. 2010-abril, 2011), 22.

96. Ibíd. Referencias citadas por María Eugenia Vázquez: Cfr. Carlos Francisco Martínez Moreno (2009) "La sociedad de los Yorkinos Federalistas, 1834. Una propuesta hermenéutica de sus estatutos y reglamentos generales a la luz de la historia de la masonería". Rehmlac 1, n 1 (mayo-nov., 2009):21233. Jordi Roca Vernet, "Política, liberalisme i revolución. Barcelona. 1820-1823". (Tesis doctoral, Universidad Autónoma de Barcelona, 2007). Irene Castells, “La resistencia liberal contra el absolutismo fernandino, 1824-1833" (2001) Ayer 41 (2001):43-62.

97. Cfr. Américo Carnicelli, La Masonería en la Independencia de América, 1810-1830 (Bogotá: Secretos de la historia, 1970), 2 vols.; Historia de la masonería colombiana, 1833-1940 (Bogotá, s.e., 1975), 2 vols. 
no se tenía la pericia suficiente para trabajar un tema que se encripta para los cánones tradicionales del oficio de historiador.

Javier Ocampo López ha demostrado, con documentos de primera mano, el reconocimiento de la presencia mental de la masonería, al acusarla del movimiento insurgente en la Nueva Granada; con un par de textos, se ilustra su aporte: "la corrupción del pueblo americano y su movimiento a la revolución, se debe a la influencia de los filósofos detestables, autores de tantos males, expresa Antonio de León en su 'Discurso político moral.' 'La filosofía del siglo XVIII, apoyada en las máximas de Wolter, Rusó, y demás espíritus fuertes, ha sido la causa del universal trastorno del Mundo'.98 Precisamente, son los herejes de la impía secta de los francmasones, quienes han impulsado la revolución:

'clase de hombres la más detestable, y peores que quantos herejes, incrédulos y libertinos ha habido, ni jamás habrá' con sus patriarcas Wiclef, Wolter, Reynald, Callostro, Rusó, y los demás hermanos terribles, como ellos los llaman. Los francmasones 'como ángeles de la bestia han rodeado toda la tierra para derramar las redomas de la ira de Dios sobre los pueblos ${ }^{\mathbf{9 9}}$.

Del texto, además de la referencia a autores como Voltaire, Rousseau, Cagliostro, el abate Raynal, algunos de los cuales tienen tradición masónica y esotérica, se alude a un término que no quisiera dejar pasar y se trata del H: Terrible, es el Q: Experto, quien interviene en la iniciación. Lo cual indica que tenían conocimientos masónicos.

Esta arqueología conceptual permite mostrar que la postura antimasónica y contrainsurgente llevada a cabo por la Iglesia y los seguidores del rey son testimonios que develan la presencia de la masonería. Algunos piensan que no, y preguntaría, ¿cómo se puede hablar del día sin conocer la noche? Se violaría el principio de no contradicción: si existe $\sim$ A es porque se reconoce la existencia de A; no puede existir la una sin la otra. Ambas se necesitan. Lo cierto es que la masonería permeó, a través de sociedades paramasónicas o secretas, a las Sociedades Patrióticas:

los últimos años de la vida de Mutis fueron también decisivos para la formación del entramado intelectual de la Nueva Granada. Consiguió, casi al comenzar el nuevo siglo, la creación de una Sociedad Patriótica, en la que colaboró activamente Jorge Tadeo Lozano -incorporado como zoólogo de la expedición-y dirigió, junto a Miguel de Isla, la reforma de los planes de los estudios médicos, a los que vinculó definitivamente con los avances de las ciencias modernas ${ }^{\mathbf{1 0 0}}$.

98. Antonio de León, "Discurso político-moral sobre la obediencia debida a los reyes y los males infinitos de la insurrección de los pueblos” (Santafé: Imprenta de B. Espinosa, 1816), 56 p. Biblioteca Nacional. Fondo Quijano Otero, 29. En Javier Ocampo López, El proceso ideológico de la Emancipación (Medellín: UPTC/La Carreta, 2010; Colección Bicentenario).

99. Ibíd., 237.

100. Especial recordación hace Miguel Ángel Puig Samper al referirse a la labor fundadora de la Sociedad Patriótica de Mutis, en el prólogo del libro de Diana Soto Arango Mutis, educador de la elite neogranadina, 12. 
Las Sociedades Patrióticas fueron un centro de organizaciones paramasónicas, que sirvieron para propagar las ideas científicas e independentistas; gran parte de los ideólogos criollos que formaron parte de la sociedad patriótica de Mutis, a la postre fueron líderes y masones iniciados.

La Sociedad Económica de Amigos del País tenía fines no necesariamente políticos: "se define como sociedades patrióticas a las reuniones de carácter político, derivadas de las tertulias ilustradas y de las Sociedades Económicas de Amigos del País, que actúan públicamente con un propósito propagandístico, por lo general con la intención de favorecer la movilización y la participación política."101 El tema de las Sociedades Económicas de Amigos del País será otro de los puntos neurálgicos en los que se pretende mostrar el pensamiento paramasónico de Mutis, pues fue un gran impulsor en la Nueva Granada:

hay que decir que las primeras Sociedades Económicas de Amigos del país, surgieron en el virreinato de la Nueva Granada, lo mismo que la prensa y las tertulias, en la década de los ochenta y noventa, a iniciativa de las personalidades como las de José Celestino Mutis, Manuel del Socorro Rodríguez y Pedro Fermín de Vargas (1762-1822). En ellas se debatieron asuntos que correspondían al deseo de los criollos de conducir al virreinato por la senda del progreso, a través de un estudio concienzudo de la realidad nacional y, sobre todo local, agrupando a los miembros del sector dirigente de cada población ${ }^{\mathbf{1 0 2}}$.

El interés de Mutis por el desarrollo de las ciencias es casi el mismo que respecto al desarrollo de las Sociedades Patrióticas, las que despliega al fundar las Sociedades Económicas de Amigos del País en toda la Nueva Granada; se encuentra en Mompox (1785), ${ }^{103}$ Quito, Popayán, además de la Sociedad de Bogotá (1801).

El pensamiento es atigrado, ya lo decía Carl Jung; ya no es posible abordar en una lógica binaria el contexto en el cual se desarrolla la masonería y los procesos de avance de la ciencia o los procesos de independencia. Hoy se consolida cada vez más la idea de que una visión positivista y polarizada de ver la Historia es inconclusa y se requiere superar la tendencia de Historia única, cronológica y universal.

En el caso de José Celestino Mutis, su aporte a las ciencias y las artes liberales se reconoce como el de un "destacado representante del movimiento ilustrado en la Nueva Granada. Como tal fue un innovador educativo, colaboró en la introducción de nuevas cátedras y fue uno de los promotores en Santafé de la creación de una

101. Del Solar Guajardo, "Secreto y sociedades secretas en la crisis del Antiguo Régimen..., 22.

102. Al respecto, puede verse el interesante capítulo dedicado a la relación de Mutis y las Sociedades Económicas de Amigos del País, por Soto Arango, Mutis, educador de la elite neogranadina, 136 ss.

103. Se le nombró miembro de honor, "estaba unido a esta ciudad por ser el sitio de residencia de su hermano y también porque había estado en la misma desde su llegada al virreinato en 1762 y, posteriormente, también se había desplazado a la Villa a realizar un estudio sobre el terreno y el cambio de lugar del cementerio." Cfr. Soto Arango, Mutis, educador de la elite neogranadina, 140. 
Sociedad Económica de Amigos del País." ${ }^{104}$ Las redes internacionales de hoy tenían, en los siglos XVIII y XIX, expresiones a través de las sociedades paramasónicas y masónicas, razón que explica la cercanía de científicos e ideólogos criollos de la independencia con los masones ingleses y suizos, algo que fue vital para Mutis y el propio Miranda. Por eso, un método que ayuda a desentrañar la criptografía en que se encuentra la masonería es la prosopografía, puesto que

en la prosopografía histórica, los francmasones tuvieron relaciones entre sí y conexiones a nivel hispanoamericano y mundial. (...) Las personas más adictas a la defensa de las libertades y más partidarias de los cambios y la revolución se hicieron 'francmasones', pues en las logias encontraron el respaldo a sus ideas revolucionarias en favor de la independencia, la libertad y el progreso de los pueblos. En sus ceremonias secretas manifestaban sus deseos por ser hombres libres y de buenas costumbres; juraban odio eterno a los gobiernos tiránicos, tanto civiles como religiosos y daban su vida por la libertad y la independencia ${ }^{105}$.

La condición masónica de Mutis puede tener sus defensores y detractores, pero, este es el criterio, aquí debo señalar que, en el caso de España, la masonería permitió incorporar

aquellos aspectos de la época de las 'luces' que no habían logrado permear a la ilustración española, la cual jamás puso en cuestión el orden político y religioso, sino que simplemente resaltó el beneficio de la ciencia para lograr el desarrollo económico. Sus protagonistas fueron reformistas al servicio de la Corona cuyo objetivo era igualar a España al resto de las naciones europeas ${ }^{\mathbf{1 0 6}}$.

A mi modo de ver, esta segunda tesis resalta la labor del sabio Mutis que, sin haber sido un masón confeso ni iniciado, llevó a cabo una labor en el desarrollo de la ciencia en la Nueva Granada y su biblioteca sirvió de fuente para el desarrollo de las ideas independentistas. Con todo el respeto, debo decir que, puestas adentro en la masonería, a José Celestino Mutis puede calificárselo como un masón sin mandil. La masonería no tiene como masones estrictamente a aquellos que han recibido iniciación, sino, además, a aquellos que hubieran sido un testimonio a la exaltación de las virtudes y desarrollo de los valores de la filosofía y la ciencia, sin fanatismos religiosos ni políticos. Así, por ejemplo, se le dio el grado masónico de Maestro masón, en forma honoraria, a François-Marie Arouet/Voltaire a la edad de 84 años, por haber considerado que su aporte filosófico sobre la tolerancia tenía un trasfondo masónico.107

104. Santiago Díaz Piedrahita, "La Ilustración en la Nueva Granada: su influencia en la educación y en el movimiento de emancipación, el caso de Mutis”, Boletín de Historia y Antigüedades 92, n 828 (marz., 2005), 127.

105. Ocampo López, El cura Juan Fernández de Sotomayor y picón y..., 269.

106. Del Solar Guajardo, "Secreto y sociedades secretas..., 145.

107. Cfr. José Antonio Ferrer Benimeli, "Voltaire y la Masonería”, La Página 77 (2009): 46-70. (Ejemplar dedicado a: Masonería y culturas), http://dialnet.unirioja.es/servlet/articulo?codigo=2999599 
La presencia de José Celestino Mutis y la Expedición Botánica constituye un tema controversial, no solo para el estudio de la Historia de la ciencia ${ }^{\mathbf{1 0 8}}$ en la Nueva Granada, sino en los antecedentes de la luz masónica. Imagínense por un momento los andamios mentales en los que se había montado el sistema colonial de enseñanza de la ciencia, cuando el solo hecho de atreverse a enseñar la física de Newton era suficiente para que lo sometiera a juicio el Santo Oficio. El primero que se atrevió a revisar el tema de Mutis y la masonería fue Santiago Díaz Piedrahita (2005), ${ }^{109}$ presidente de la Academia Colombiana de Historia, con un trabajo intitulado "La Ilustración en la Nueva Granada: su influencia en la educación y en el movimiento de emancipación, el caso de Mutis", y que corresponde a una ponencia en el IX Congreso de Academias Iberoamericanas de Historia, en Madrid, en noviembre de 2004 .

A la gran biblioteca de Mutis la apeteció mucho la intelectualidad criolla; sin embargo, en los estudios sobre la Historia de la ciencia en Colombia, ${ }^{\mathbf{1 1 0}}$ poco o nada se alude a los libros que la componían, lo cual reviste un gran interés hoy por hoy:

"Es difícil entender cómo Mutis, bajo las condiciones de la época, logró centralizar en Santafé de Bogotá, una ciudad mediterránea, mal comunicada y ubicada a 2.600 metros de altitud, una extraordinaria colección de libros. Parte de tal biblioteca fue traída por el propio Mutis y parte le fue proporcionada por la corte, una vez puesta en marcha la Expedición; pero el grueso de ella se formó gracias a su correspondencia con los científicos de Europa y al hecho de invertir buena porción de sus ingresos en la compra de importantes obras a través de distintos proveedores. En 1802 Humboldt, luego de conocerla, la consideró comparable en calidad y casi similar en número de obras a la de Sir Joseph Banks, acaudalado y notable viajero y naturalista que alcanzó renombre como filántropo y presidente de la Real Sociedad de Inglaterra. En esta biblioteca figuraban las principales obras del momento y se actualizaba permanentemente con nuevos títulos; tan solo disminuyó el ingreso de novedades cuando, por razones de la guerra con Inglaterra, la navegación se hizo difícil y los viajes y remesas empezaron a demorar más de lo normal. Esta colección aún hoy es motivo de admiración y en su momento deslumbró a unos cuantos privilegiados que tuvieron acceso a ella. Todos los jóvenes

108. “Recién establecido en Santafé trató sin éxito de dictar la cátedra de medicina en el Colegio del Rosario; en 1802, con la colaboración de Miguel de Isla, por fin pudo abrirla con lujo de detalles y con un programa innovador. En 1762 había inaugurado la cátedra de matemáticas en el mismo Colegio Mayor teniendo como meta la de capacitar a la juventud en los estudios filosóficos a través de las ciencias exactas. En más de una oportunidad denunció el estado de la educación, inculpando a las órdenes religiosas por impedir el desarrollo de una verdadera universidad. En 1764 asumió la cátedra de física y expuso las ideas de Newton, Copérnico y Galileo. Esto dio pie para que, en 1768, y presuntamente por enseñar herejías, se le acusase en forma mojigata ante la Santa Inquisición." En Ferrer Benimeli “Aproximación a la historiografía de la masonería latinoamericana”, 120

109. Díaz Piedrahita, "La Ilustración en la Nueva Granada: su influencia en la educación y en el movimiento de emancipación, el caso de Mutis".

110. Gabriel Restrepo, "Elementos teóricos para una historia social de la ciencia en Colombia", en Carlos Eduardo Vasco, coord., Historia Social de la Ciencia en Colombia (Bogotá: Tercer Mundo, 1993), vol. 1. 
que allí complementaron su educación contribuyeron en forma decisiva a la emancipación e independencia de la Nueva Granada ${ }^{\mathbf{1 1 1}}$.

Hay algunas implicaciones que se pueden inferir de esta cita: la primera, el señalar la importancia de la biblioteca en la formación intelectual de la elite criolla ${ }^{112}$. Y la segunda, que estos jóvenes formaron parte de los ideólogos criollos:

"En el Nuevo reino de Granada son expresantes de la revolución criolla, entre otros personajes: José Félix de Restrepo, ${ }^{\mathbf{1 1 3}}$ Camilo Torres, Pedro Fermín de Vargas, Antonio Nariño, Francisco José de Caldas, Joaquín Camacho, Frutos Joaquín Gutiérrez, Ignacio de Herrera, José Ignacio de Pombo, José María Carbonell, Francisco Antonio Zea,114 José María Cabal, José María García de Toledo, Antonio Baraya, Jorge Tadeo Lozano, Joaquín Caycedo y Cuero, José Acevedo y Gómez, Antonio Villavicencio, José María del Castillo y Rada, Emigdio Benítez, Miguel de Pombo, Custodio García Rovira, José Manuel Restrepo, Antonio Ricaurte, Manuel Rodríguez Torices, Juan del Corral, Francisco de Paula Santander, José Ignacio de Márquez, y otros criollos (...) Entre los criollos granadinos, unos manifiestan el tipo del gran aventurero o precursores, como es el caso de Antonio Nariño y Pedro Fermín de Vargas. Son personajes característicos de los finales del siglo XVIII; recibidos en las cortes europeas; francmasones (...) pertenecientes a sociedades secretas y luchadores infatigables por la Independencia"115.

111. Díaz Piedrahita, “La Ilustración en la Nueva Granada..., 122.

112. Gran parte de la generación independentista neogranadina pasó por la biblioteca de Mutis: "Entre las bibliotecas privadas se encuentran, entre otras, la del propio Mutis, la de Caldas, la de Camilo Torres y la de Antonio Nariño. Los textos pertenecían a autores que procedían de la Ilustración española, francesa e inglesa; libros de autores políticos como Voltaire, Diderot, Rousseau y de científicos... Las tertulias constituyeron otro medio para la difusión de las ideas Ilustradas (...) La de Antonio Nariño y Álvarez, llamada 'El Arcano de la Filantropía'. Éste un recinto en el fondo de su casa, llamado el santuario, donde se reunían supuestamente a conspirar ilustrados como Luis de Rieux, José María Cabal, Francisco Antonio Zea, José María Lozano, Pedro Fermín de Vargas, Enrique Umaña, José Luis Azuola, José Antonio y Juan Esteban Ricaurte; Sinforoso Mutis y Francisco Tobar." Soto Arango, Mutis, educador de la elite neogranadina, 145.

113. Fue discípulo de Mutis: “Cuando estudiaba en el real Colegio de San Bartolomé, el joven José Félix de Restrepo, dedicado a sus estudios de filosofía y jurisprudencia, recibió también las influencias del sabio José Celestino Mutis (...) Así la Generación Precursora de la Independencia se formó alrededor de las nuevas ideas de la Ilustración, con sus dos Grandes Maestros: el Sabio José Celestino Mutis desde Santafé de Bogotá y el Maestro Dr. José Félix de Restrepo desde Popayán." Javier Ocampo López, "El maestro José Félix de Restrepo, el educador de la generación de Independencia de Colombia”, en Rhela 14, (2010), 17, Rudecolombia/UPTC. José Félix de Restrepo, tío de Francisco Antonio Zea, nativo de Envigado, Antioquia.

114. “Nació en la villa de Medellín, el 23 de noviembre de 1766 y murió el 28 de noviembre de 1822 en el York House Hotel, de la ciudad de Bath, Inglaterra, a la edad de 51 años. Zea tuvo a su favor el ser hijo de nobles, hecho que le permitió ingresar como estudiante del Colegio de Popayán y colegial en el Mayor de San Bartolomé de Santa Fe de Bogotá. Fue discípulo de José Félix Restrepo y compañero con Caldas y Torres. Zea empieza su vida profesional en 1788, como catedrático de gramática en el Colegio de San Bartolomé y en 1791 el virrey Ezpeleta le encargó la educación de sus hijos y en este mismo año se le nombra, por petición de Mutis, subdirector de la Real Expedición Botánica de la Nueva Granada. Participó en la tertulia «El Arcano de la Filantropía», que coordinaba Nariño y que, luego, fuera el motivo principal para su detención en 1795." Diana Soto Arango, "Francisco Antonio Zea: periodista, botánico y político", Asclepio 48, n 1 (1996), 124, http://asclepio.revistas.csic.es

115. Ocampo López, El proceso ideológico de la Emancipación, 88. 
Y, la tercera, que gran parte de los ideólogos que pasaron por las manos formativas de Mutis se implicaron en levantamientos conspirativos y abrazaron la luz masónica. Hoy se pregunta, ¿será una casualidad? Con la licencia de los más ortodoxos, quizá se pueda decir, con palabras del Gran Maestro de la Gran Logia de Guadalajara, quien me manifestó que "la masonería es como el aire, se siente pero no se ve"116.

Piedrahita mantiene una posición parca a la hora de pronunciarse sobre la condición masónica de Mutis y solo señala que

fue un destacado representante del movimiento ilustrado en la Nueva Granada. Como tal fue un innovador educativo, colaboró en la introducción de nuevas cátedras y fue uno de los promotores en Santafé de la creación de una Sociedad Económica de Amigos del País. La Expedición Botánica respondía a los postulados de las políticas ilustradas y en su seno se formaron en la ciencia varios jóvenes que actuaron como líderes del movimiento de emancipación. No existen bases para pensar que José Celestino Mutis haya tenido nexos con la masonería ${ }^{117}$.

Con José Celestino Mutis sucede lo mismo que con Francisco de Miranda, pues no hay testimonios fehacientes de su vinculación con la masonería, si por ello se entiende cartas de adopción o cartas de iniciación en las logias madres a las que hubieran pertenecido. No quisiera especular, pero permítaseme presentar un argumento, sin que eso implique que estoy haciendo uso de un argumentum ad verecundiam, y se trata de lo siguiente: en el caso de Simón Bolívar, siempre la historiografía mantuvo que no había sido masón, hasta que Ramón Díaz Sánchez se encontró, en 1956, el certificado de Compagnon, ${ }^{\mathbf{1 1 8}}$ por la Logia Saint Alexandre de Escocia de París. Pero obsérvese, en ninguna de las casi 11.000 cartas, ni en los documentos fundamentales hizo confesión masónica alguna; es más, se pudiera decir que más bien hay testimonios de actitudes antimasónicas, cuando mandó a prohibir la masonería en el Decreto del 8 de noviembre de 1828 que, como se sabe, respondió a razones políticas. No hay ninguna contradicción; de Pablo Morillo ${ }^{119}$ se dice que fue masón y, sin embargo, fue el más acérrimo e inclemente perseguidor de patriotas, ${ }^{\mathbf{1 2 0}}$ hasta llevar al patíbulo a la más excelsa elite criolla

116. José Pascual Mora García, "La masonería en la nación venezolana (s. XVIII - XIX)", Conferencia realizada en la Universidad de Guadalajara, Departamento de Estudios Mesoamericanos y Mexicanos, Guadalajara, México (17 de diciembre de 2008).

117. Díaz Piedrahita, “La Ilustración en la Nueva Granada..., 127.

118. “El historiador Ramón Díaz Sánchez adquirió en París el documento manuscrito, en lengua francesa, relativo a la recepción masónica de Simón Bolívar en el Grado de Compañero, y que entregó en propiedad, el $1^{\circ}$ de octubre de 1956, al Supremo Consejo del Grado 33 de Venezuela. La recepción de Bolívar tuvo lugar, según el Diploma, "el undécimo día del undécimo mes del año de la Gran Luz 5805”; es decir, el 11 de noviembre de 1805”. Cfr. "Bolívar y la masonería”, http://granlogia. wordpress.com/resena-historica/bolivar-en-la-maso neria/, consultada 2010.

119. Luis Corsi Otálora, “Abril, mayo, julio 1810: ¿Chispas o Petardos?”, Revista Repertorio Boyacense 98, $\mathrm{n}^{\circ} 347$ (julio 2009), 202. Refiere el autor que Pablo Morillo fue "antiguo sargento masón, protegido por los ingleses", 202.

120. Hay posiciones en la vida de Pablo Morillo que algunos le atribuyen una condición masónica, como, por ejemplo, el famoso abrazo de Bolívar y Morillo en Santa Ana de Trujillo (Venezuela), con ocasión de la pacificación. Algunos argumentan que ambos se reconocieron en su condición masónica. Hay 
neogranadina en aquel infausto año de 1816, cuando también rindió la vida, en el fusilamiento de la Huerta de Jaime, el tachirense, nativo de La Grita, Francisco Javier García de Hevia. ${ }^{\mathbf{1 2 1}}$ Por tanto, no hay ninguna razón suficiente como para descalificar la condición masónica por no haber evidencia de pertenecer a una logia. No se pretende establecer conclusiones terminantes, sino abrir el debate.

\section{FRANCISCO ANTONIO ZEA, MASÓN}

Ya se ha adelantado algo sobre la posible vinculación del sabio Mutis con la masonería, incluso se ha alertado que masón no solo es quien es iniciado, sino quien lleva una vida en la cual se observan las virtudes de la masonería. La masonería, en sentido lato, también incluye a masón sin mandil.

La presencia de Francisco Antonio Zea se debe resaltar, sobre todo por la trayectoria como científico e ideólogo de la independencia. Quizá Mutis nunca se imaginó que su obra podría tener un seguidor tan brillante, pero, sin duda, es Zea el más oportuno para resaltar el plan educativo del sabio gaditano en tierra neogranadina.

Luego de que lo descubren en la conspiración de 1794, lo envían prisionero a España, y, al salir del cautiverio, recibe un trato especial, en el que llega incluso ser director del Real Jardín Botánico de Madrid122:

Zea quedó marcado, en lo científico y en lo político, por su estancia en París. En la capital gala establece relación con los directores de los periódicos y realiza pequeñas reseñas sobre los botánicos españoles, donde él también se incluía. A su regreso a Madrid, ya como segundo profesor del Jardín Botánico y, en especial, como director de La Gazeta y El Mercurio - de Madrid, refleja su tendencia francesa en las informaciones políticas y científicas que difunde desde estos dos diarios. El Mercurio, periódico estatal, se componía de dos apartados: el político y el literario. En la sección política, Zea expresó sin reparo su apoyo y admiración hacia el gobierno y científicos franceses. Es significativo que desde el primer número, se declaró admirador de Napoleón y le llegó a considerar el salvador de Francia ${ }^{\mathbf{1 2 3}}$.

otro hecho que refiere Justo Cuño Bonito, El retorno del Rey: el restablecimiento del régimen colonial en Cartagena de Indias (1815-1821) (Castellón: Universitat Jaume I, 2008). Perdonó a Arismendi, de quien se dice que era masón, aun en contra de Morales; "Morillo, sin embargo, perdonó a Arismendi conminándole a que se levantara: 'Arismendi, levántese, consuélese y sea leal en adelante con esta nación hidalga, a quien debe una segunda vida.", 29. También se carteó con Nariño, a quien llamaba por el alias de Enrique Somoyar, 27.

121. Jorge Duarte Acero, (2016) “El Doctor Francisco Javier García de Hevia, el mártir de la independencia nativo del cantón de La Grita”. Revista El Táchira Honra a Bolívar 28 (2016):13-40, http://erevistas. saber.ula.ve/index.php/sociedadbolivarianatachira/article/view/7765/7691

122. "Francisco Antonio Zea deja la dirección de los periódicos La Gaceta y El Mercurio cuando pasa a ocupar la dirección del Real Jardín Botánico. En su nuevo cargo pudo desarrollar gran parte de las iniciativas que venía planteando en los citados periódicos, sobre la botánica y la agricultura. En estos planes contó siempre con el apoyo del grupo francófilo y en especial con la aprobación del ministro Godoy y del Secretario de Estado Pedro Cevallos". Soto Arango, "Francisco Antonio Zea: periodista, botánico y político", 130.

123. Soto Arango, "Francisco Antonio Zea: periodista, botánico y político", 127-28. 
Se quiere destacar, para efectos de este estudio, una posible conexión de Zea con la masonería francesa, dado que José I, hermano de Napoleón Bonaparte, se interesó mucho en el desarrollo de la masonería en España. Esto puede ser determinante para poder explicar la cercanía de Zea con la Corte francesa, en España. La cercanía de Zea con los franceses la destaca Miguel Ángel Puig Samper, al resaltar la obra de Diana Soto Arango sobre Francisco Antonio Zea: "una de las contribuciones del libro que prologamos es, sin duda, la actividad de Zea durante la ocupación napoleónica, que pasó a ocupar un puesto importante del Ministerio del Interior de José I, tras haber sido firmante de la Constitución de Bayona junto a sus protectores Pedro Cevallos y Zenón Alonso"124.

A su retorno a la Nueva Granada, se vincula con la gesta independentista y, así, se lo encuentra ocupando un rol significativo como

dirigente político revolucionario. El centro de operaciones políticas fue la ciudad de Angostura. Desde esta población fundó y orientó el Correo del Orinoco. Al movimiento revolucionario de la independencia se vincula por medio de Miranda. Parece ser que el grupo de la masonería francesa, a la que pertenecían Bolívar y Miranda, y posiblemente también Zea, apoyará la gesta libertaria de las colonias americanas ${ }^{\mathbf{1 2 5}}$.

El compromiso con la masonería fue seguramente una de las motivaciones para retornar a América; de seguro el recuerdo de los compromisos con Nariño, y el propio Mutis, en el fondo de su corazón animaron su retorno a la causa patriota:

Conviene destacar que el impacto que estaba cobrando el movimiento de la independencia americana en Europa y su amistad con Miranda no fue lo único que le llevó a trasladarse a América. Consideramos que mediaban intereses más fuertes, como eran posiblemente los de la masonería que, en su relación más o menos directa, le conducen a viajar, en la primavera de 1815 , a la isla de Santo Domingo, donde conoce a Bolívar. Es importante apuntar que desde esta fecha se establece una estrecha amistad con el «libertador». De hecho, se convertiría más adelante en uno de sus más fieles consejeros en la elaboración del perfil que se le daría a la Constitución de la denominada Gran Colombia y como vice-presidente de esta naciente República ${ }^{\mathbf{1 2 6}}$.

La brillante carrera de Zea es, sin duda, una de las más admirables; en testimonio a su labor masónica, se evidencia la cooperación de las redes en los principios y valores de los masones.

124. Miguel Ángel Puig Samper, "Prólogo", en Diana Soto Arango, Francisco Antonio Zea, un criollo ilustrado (Madrid: Doce Calles, 2000), 14. Destaca, también, la presencia de José María Lanz, quien ocupó un alto cargo como Ministro del Interior josefino y a José Mariano Mociño, quien dirigió el Real Gabinete de Historia Natural y llegó a ser Presidente de la Academia Médica Matritense. José María Lanz, de confesiones masónicas.

125. Soto Arango, "Francisco Antonio Zea: periodista, botánico y político", 139.

126. Ibíd., 139. 


\section{CONCLUSIONES}

Aquí se destaca que Francisco de Miranda fue un ideólogo fundamental del proceso independentista y, aunque no se ha probado su condición masónica, su trayectoria puede reconocerse como de inspiración masónica. Sus obras y su biblioteca hablan de masonería y si, como dice Le Goff, las bibliotecas indican la mentalidad del autor, entonces se puede afirmar que la discreción de la orden bien pudiera justificar ese silencio. Lo propio sucede con Mutis: las conexiones científicas o de poder eran con masones confesos: "lo que sí es un hecho es que para comunicarse con Carlos Linneo y con otros naturalistas suecos se valió de los cónsules de tal país en Cádiz, especialmente de Bellman y de Juan Jacobo Gahn, quienes sí tuvieron vínculos con las logias"127.

Hay una variable significativa que, como estudioso de las mentalidades, me atrevo a señalar, y es que el mismo Ferrer Benimeli invita a una visión revisionista sobre la masonería en América Latina, incluso a buscar en nuevas fuentes y en métodos que puedan dar nuevas ideas. Él señala algunas claves acerca del silencio del compromiso masónico de algunos de los ideólogos y científicos, cuyas protorepresentaciones inducen al menos a actitudes paramasónicas.

Es un hecho que la masonería en las colonias inglesas se permitía, y en las colonias españolas se sancionaba:

mientras en toda la América hispana la masonería estuvo prohibida y perseguida tanto por los Tribunales de Inquisición como por los edictos de los reyes, las antiguas colonias inglesas siguieron la tradición y el ejemplo de Gran Bretaña de forma tal que la institución masónica a la que pertenecían importantes hombres de política y el ejército logró una rápida implantación con la creación de las Grandes Logias en los estados que se iban formando ${ }^{\mathbf{1 2 8}}$.

La masonería ingresa a la Nueva Granada por Cartagena de Indias, afiliada al Or: de Jamaica y la primera Logia Britannia $\mathrm{N}^{\circ} 1$, y Cartagena es el epicentro del proceso Juntista en busca del proceso independentista en 1810. Mutis mantuvo mucha relación con Sociedades Patrióticas de Cartagena y Mompox, y en Cartagena ejerció el episcopado el obispo masón Juan Fernández de Sotomayor y Picón ${ }^{\mathbf{1 2 9}}$. Los implicados en el levantamiento que encabezó Antonio Nariño eran discípulos

127. Díaz Piedrahita, “La Ilustración en la Nueva Granada..., 122.

128. José Antonio Ferrer Benimeli, “Vías de penetración de la masonería en el Caribe”, Rehmlac $1, \mathrm{n}^{\circ} 1$, (mayo-dic. 2009), 3.

129. "Este clérigo neogranadino, natural de Cartagena de Indias es conocido en la historia de Colombia como El 'Cura de Mompox', pues fue quien, antes del cura mexicano Miguel Hidalgo, con su célebre 'Grito de Dolores', del 16 de septiembre de 1810, apoyó la independencia absoluta de Mompox, el 6 de agosto de 1810, la primera en Hispanoamérica. Fue autor del catecismo o instrucción popular, que sintetiza la teoría de la independencia de Hispanoamérica, obra por la cual fue perseguido por la Santa Inquisición de Cartagena y por las autoridades realistas en los años de la reconquista española, llamado 'Régimen del terror'”. Ocampo López, El cura Juan Fernández de Sotomayor y Picón y los catecismos de la Independencia, 9. 
de Mutis, en el que incluso su sobrino, Sinforoso Mutis ${ }^{\mathbf{1 3 0}}$ salió implicado en 1794. En el Colegio Mayor de Nuestra Señora del Rosario ejerció la docencia Mutis; fueron centros de formación y difusión de científicos e ideólogos que tuvieron, después, compromisos con la masonería. La Sociedad Patriótica tuvo sus repercusiones a través de las Sociedades de Economía y de Amigos del País, centros para difundir ideas políticas y de ciencia.

El tema ha merecido más interés por historiadores españoles ${ }^{\mathbf{1 3 1}}$ que en Latinoamérica, por eso es necesario seguir apostando a la investigación histórica e historiográfica, revisar nuevos archivos e incorporar los métodos actuales de la historia.

130. Era sobrino del sabio José Celestino Mutis y, tras la muerte de su hermano Manuel, había asumido la responsabilidad de formarlo: “Sinforoso perseveró en los estudios, pero se rebeló contra el tío y no quiso seguir una carrera vinculada a las ciencias naturales, sino que optó por la jurisprudencia. (...) Esta afinidad habría de depararle sus mayores tribulaciones cuando en 1794, tras haberse hecho asiduo asistente a las tertulias patrocinadas por don Antonio Nariño, Sinforoso resultó comprometido en la llamada conspiración de los pasquines, donde también estaban implicados el mismo Nariño, Francisco Antonio Zea, José María Lozano, y varios jóvenes más, la mayoría estudiantes del Rosario y para mayor tribulación discípulos de Mutis (...) Sinforoso y sus cómplices fueron desterrados a Cádiz, donde permanecieron recluidos hasta abril de 1799 en el castillo de San Sebastián." España, Mutis y la expedición botánica, 63-65.

131. En España, desde la década de 1980, el núcleo dinamizador de los estudios históricos sobre la masonería ha sido el Centro de Estudios Históricos de la Masonería española [Cehme], como señala Yván Pozuelo Andrés en La Historiografía masónica latinoamericanista actual. Presente y Futuro (Santiago de Compostela, 2010)", José Antonio Ferrer Benimeli, "Aproximación a la historiografía de la masonería latinoamericana", 6. Desde el punto de vista metodológico, véase: José Antonio Ferrer Benimeli, La historia ante la masonería. Reflexiones Metodológicas, El basilisco 9 (en.-abr., 1980):31-40; y Método y experiencias en el estudio de la historia de la masonería española, y en Éric Saunier, La prosopografía, una nueva vía para la historia de la Masonería, Rehmlac 1, n 2 (dic. 2009 abr. 2010):44-62, 37-43. 


\section{REFERENCIAS BIBLIOGRÁFICAS}

Bachelard, Gaston. 1985. El Nuevo Espíritu Científico. 2ª ed. México: Nueva Imagen.

Carnicelli, Américo. 1970. La Masonería en la Independencia de América, 1810-1830. Bogotá: Secretos de la Historia, 2 vols.

Combes, André. 2007. Les trois siécles de la Franc-maçonnerie Française. París: Éditions Dervy.

Corsi Otálora, Luis. 2009. Abril, mayo, julio 1810: ¿Chispas o Petardos? Revista Repertorio Boyacense 98, $\mathrm{n}^{\circ} 347$ (julio), http://fundacionspeiro.org/downloads/magazines/ docs/pdfs/613_abril-mayo-julio1810-chispas-o-petardos-independencia-hispano-americana -espejismo-tragico.pdf

Cuño Bonito, Justo. 2008. El retorno del Rey: el restablecimiento del régimen colonial en Cartagena de Indias (1815-1821). Castellón: Universitat Jaume I.

Del Solar Guajardo, Felipe Santiago. 2011-12. Secreto y sociedades secretas en la crisis del Antiguo Régimen. Reflexiones para una historia interconectada en el mundo hispánico. Rehmlac 3, n 2 (dic.-abr.):133-56.

España, Gonzalo. 1999. Mutis y la Expedición Botánica. Bogotá: Panamericana.

Ferrer Benimeli, José. 1974. Bibliografía de la masonería. Introducción histórico-crítica. Caracas: Universidad Católica "Andrés Bello".

.1976. Los archivos secretos vaticanos y la masonería. Motivos políticos de una condena pontificia. Caracas: Universidad Católica "Andrés Bello".

_. Feijoo y la masonería. 1983. En II Simposio sobre el Padre Feijoo y su siglo, 2, 349-62. Oviedo: Centro de Estudios del siglo XVIII.

_. 2009. Voltaire y la Masonería. La Página 77 (ejemplar dedicado a: Masonería y culturas):46-70. http:// dialnet.unirioja.es/servlet/articulo?codigo $=2999599$

_. 2009. Vías de penetración de la masonería en el Caribe. Rehmlac 1, nº 1 (mayo-dic.):2-18.

Le Goff, Jacques. 1980. La historia de las mentalidades, una historia ambigua, en Le Goff, Jacques y Pierre Nora. 1980. Hacer la historia. Barcelona: Laia. Vol. 3.

León, Antonio de. 1816. Discurso político-moral sobre la obediencia debida a los reyes y los males infinitos de la insurrección de los pueblos. Santafé: Imprenta de B. Espinosa. En: Ocampo López, Javier. 2010. El proceso ideológico de la Emancipación. Medellín: UPTC/La Carreta. Colección Bicentenario.

Martínez Moreno, Carlos Francisco. 2009. La sociedad de los Yorkinos Federalistas, 1834. Una propuesta hermenéutica de sus estatutos y reglamentos generales a la luz de la historia de la masonería. Rehmlac 1 , $\mathrm{n}^{\circ} 1$ (mayo-nov.):212-33.

Mata Marchena, Juan Diego. 2001-2002. Una visión del siglo XVIII español. Cuadernos sobre Vico 13-14, 371-83.

Mora García, José Pascual. 2009. Los comuneros, Francisco De Miranda y la francmasonería en Venezuela (1779-1810). Heurística (Mérida, Venezuela) 11 (enero-junio):74-92. www.saber.ula.ve/bitstream/1234 56789/30649/1/articulo7.pdf.

_.2011. La Masonería. Su historia y su contribución en la construcción simbólica de la nación venezolana, en Guzmán Pérez, Moisés, coord. Liberalismo, Masonería e Independencias en Hispanoamérica. Morelia, México: en prensa.

2010. Los masones en la construcción simbólica de la nación venezolana (Del Estado protonacional a la conformación del Estado Nación decimonónico)". En Soto Arango, Diana; Justo Cuño Bonito; José Tomás

Mutis, José Celestino. 1981. Documentos sobre el sistema copernicano, Revista Correo de Los Andes 21 (sept.-oct.). En Soto Arango, Diana. 2005. Mutis, educador de la elite neogranadina. 
Ocampo López, Javier. 2010. El cura Juan Fernández de Sotomayor y Picón y los catecismos de la Independencia. Bogotá: Universidad del Rosario.

_. 2010. El maestro José Félix de Restrepo, el educador de la generación de Independencia de Colombia. Rhela 14, 9-60.

_. 2010. El proceso ideológico de la Emancipación. Medellín: UPTC/La Carreta. Colección Bicentenario.

Pozuelo Andrés, Yván. 2009-10. La masonería: ¿Una organización discreta? Rehmlac 1, n 2 (dic.-abril):62-87. En Del Solar Guajardo, Felipe Santiago. 2011-12. Secreto y sociedades secretas en la crisis del Antiguo Régimen. Reflexiones para una historia interconectada en el mundo hispánico. Rehmlac 3, n 2 (dic.-abril):133-56.

Puig Samper, Miguel Ángel. 2000. Prólogo. En Soto Arango, Diana. Francisco Antonio Zea, un criollo ilustrado. Madrid: Doce Calles.

Restrepo, Gabriel. Elementos teóricos para una historia social de la ciencia en Colombia, en Vasco, Carlos Eduardo, coord. 1993. Historia Social de la Ciencia en Colombia. Bogotá: Tercer Mundo. Vol. 1.

Roca Vernet, Jordi. “Política, liberalisme i revolución. Barcelona. 1820-1823”. Tesis doctoral, Universidad Autónoma de Barcelona, 2007.

Soto Arango, Diana. 2005. Mutis, educador de la elite neogranadina. Tunja: Rudecolombia/UPTC.

_. 2000. Francisco Antonio Zea, un criollo ilustrado. Madrid: Doce Calles.

_. 1996. Francisco Antonio Zea: periodista, botánico y político. Asclepio 48. http://asclepio.revistas.csic.es

Soto Arango, Diana; Justo Cuño Bonito; José Tomás Uribe y Olga Acuña, eds. 2010. La Construcción de la nación Iberoamericana. Siglos XIX a XXI. Conceptos y Métodos para la Historia y la Construcción de la Nación. Tunja: Rudecolombia/UPTC/Centro Vendimia/Grupo Hisula.

Uribe y Olga Acuña, eds. La Construcción de la nación Iberoamericana. Siglos XIX a XXI. Conceptos y Métodos para la Historia y la Construcción de la Nación, 159-78. Tunja: Rudecolombia/UPTC/Centro Vendimia/ Grupo HISULA.

_. La masonería en la nación venezolana (s. XVIII - XIX). Conferencia realizada en la Universidad de Guadalajara, Departamento de Estudios Mesoamericanos y Mexicanos. Guadalajara, México, el 17 de diciembre de 2008.

Vázquez Semadeni, María Eugenia. 2010-11. La masonería en México, entre las sociedades secretas y patrióticas (1813-1830). Rehmlac 2, n² 2 (dic.-abril):18-33. 